\title{
Biochemical characteristics and molecular mechanism of an exo-type alginate lyase VxAly7D and its use for the preparation of unsaturated monosaccharides
}

\author{
Luyao Tang ${ }^{1,2}$, Ying Wang ${ }^{1,2,3}$, Shan Gao ${ }^{1,2}$, Hao Wu ${ }^{1,2}$, Danni Wang ${ }^{1,2}$, Wengong Yu ${ }^{1,2^{*}}$ and Feng Han ${ }^{1,2^{*}}$ (1)
}

\begin{abstract}
Background: As the most abundant polysaccharide in brown algae, alginate has become a promising economical material for bioethanol production. Recently, exo-type alginate lyases have received extensive attention because the unsaturated monosaccharides produced by their degradation of alginate can be easily converted into 4-deoxyL-erythro-5-hexoseulose uronate (DEH), a promising material for bioethanol production and biorefinery systems.

Results: In this study, we cloned and characterized an exo-type polysaccharide lyase family 7 (PL7) alginate lyase VxAly7D from the marine bacterium Vibrio xiamenensis QY104. Recombinant VxAly7D was most active at $30{ }^{\circ} \mathrm{C}$ and exhibited $21 \%, 46 \%$ and $90 \%$ of its highest activity at 0,10 and $20^{\circ} \mathrm{C}$, respectively. Compared with other exo-type alginate lyases, recombinant VxAly7D was shown to be a bifunctional alginate lyase with higher specific activity towards sodium alginate, polyG and polyM ( $462.4 \pm 0.64,357.37 \pm 0.53$ and $441.94 \pm 2.46 \mathrm{U} / \mathrm{mg}$, respectively). A total of $13 \mu \mathrm{g}$ recombinant $V x A l y 7 D$ could convert $3 \mathrm{mg}$ sodium alginate to unsaturated monosaccharides in 1 min with a yield of $37.6 \%$, and the yield reached $95 \%$ in $1 \mathrm{~h}$. In addition, the three-dimensional structure of VxAly7D was modelled using the crystal structure of AlyA5 from Zobellia galactanivorans Dsij ${ }^{\top}$ as the template. The action mode and the end products of the W295A mutant revealed that Trp 295 is a key amino acid residue responsible for the exolytic action mode of VxAly7D.
\end{abstract}

Conclusion: Overall, our results show that VXAly7D is a PL7 exo-type alginate lyase with high activity and a high conversion rate at low/moderate temperatures, which provides a useful enzymatic tool for the development of biofuel production from brown algae and enriches the understanding of the structure and functional relationships of polysaccharide lyases.

Keywords: Alginate, Alginate lyase, Exo-type, Polysaccharide lyase, Monosaccharide, 4-Deoxy-L-erythro-5hexoseulose uronate (DEH), Vibrio

*Correspondence: yuwg66@ouc.edu.cn; fhan@ouc.edu.cn

${ }^{1}$ Key Laboratory of Marine Drugs, Ministry of Education; Shandong Provincial Key Laboratory of Glycoscience and Glycoengineering, School of Medicine and Pharmacy, Ocean University of China, 5 Yushan Road, Qingdao 266003, China

Full list of author information is available at the end of the article

\section{Background}

With the demand for energy growing constantly and fossil fuel resources being depleted, bioethanol has received more attention as renewable, clean energy [1-3]. Brown algae have become an important source of bioethanol production because of showing excellent characteristics including a wide distribution, high productivity, and

(C) The Author(s) 2020. This article is licensed under a Creative Commons Attribution 4.0 International License, which permits use, sharing, adaptation, distribution and reproduction in any medium or format, as long as you give appropriate credit to the original author(s) and the source, provide a link to the Creative Commons licence, and indicate if changes were made. The images or other third party material in this article are included in the article's Creative Commons licence, unless indicated otherwise in a credit line to the material. If material is not included in the article's Creative Commons licence and your intended use is not permitted by statutory regulation or exceeds the permitted use, you will need to obtain permission directly from the copyright holder. To view a copy of this licence, visit http://creativecommons.org/licenses/by/4.0/. The Creative Commons Public Domain Dedication waiver (http://creativecommons.org/publicdomain/zero/1.0/) applies to the data made available in this article, unless otherwise stated in a credit line to the data. 
absence of lignin, without requiring arable land, freshwater, or fertilizer [4-6].

Alginate is the major polysaccharide of the cell wall in brown algae, which may account for $40 \%$ of the dry weight of brown algae [7, 8]. Alginate is a linear polysaccharide consisting of $\beta$-D-mannuronate $(M)$ and its $\mathrm{C} 5$ epimer $\alpha$-L-guluronate $(\mathrm{G})$ connected by 1,4 O-linked glycosidic bonds [9, 10], arranged as poly $\beta$-Dmannuronate (polyM), poly $\alpha$-L-guluronate (polyG) or their heteropolymer (polyMG) [11]. Alginate and its oligosaccharides exhibit high safety and are widely used in food, medicine and industrial production [12].

Alginate lyase degrades alginate via the $\beta$-elimination reaction, producing unsaturated $\mathrm{C}=\mathrm{C}$ double bonds between $\mathrm{C} 4$ and $\mathrm{C} 5$ at the nonreducing end [13]. Thousands of alginate lyases have been discovered, and more than a hundred of these enzymes have been characterized. However, only a few of these enzymes show high activity at low/moderate temperatures [14-20]. Alginate lyases with high activity and stability at low/moderate temperatures are suitable for many industrial productions purposes because they can be selectively inactivated by slightly increasing the temperature, which can save energy and reduce biological pollution [17, 21-23]. According to substrate specificities, alginate lyases are classified into polyM-specific lyases (EC 4.2.2.3), polyGspecific lyases (EC 4.2.2.11) and bifunctional lyases (EC 4.2.2.-). Based on amino acid sequence analysis, alginate lyases are classified into 12 polysaccharide lyase (PL) families (PL5, 6, 7, 14, 15, 17, 18, 31, 32, 34, 36, and 39) in the Carbohydrate-Active enZYmes (CAZy) database (http://www.cazy.org/). Based on differences in the action mode, alginate lyases can be further divided into endoand exo-types [24]. Most of the known alginate lyases are of the endo-type and degrade alginate into unsaturated oligosaccharides with different degrees of polymerization (DP) [25-27]. Exo-type alginate lyases are classified as PL6, 7, 14, 15, or 17 family, and degrade alginate polymers and oligomers into unsaturated monosaccharides. The unsaturated monosaccharides are nonenzymatically transformed into 4-deoxy-L-erythro-5-hexoseulose uronate (DEH), an essential intermediate in the physiological metabolism of alginate and a potential carbon source for the production of bioethanol and biorefinery [28]. DEH can be reduced to 2-keto-3-deoxygluconate (KDG) by the reductase DehR and feeds into the Entner-Doudoroff (ED) pathway to produce ethanol $[4,6]$. Therefore, the degradation of alginate to unsaturated monosaccharides is a crucial step for the production of bioethanol.

However, the specific activity of most currently reported exo-type alginate lyases were approximately $20-70 \mathrm{U} / \mathrm{mg}$ [29-34], resulting in a low alginate degradation rate and unsaturated monosaccharide yield. Some of these enzymes even show apparent substrate preferences [32, 35-37], which limits the choice of possible substrates and affects the process of industrialization. To efficiently degrade alginate to produce unsaturated monosaccharides, it has recently been proposed to exploit the synergistic effects of endolytic and exolytic alginate lyases $[4,6$, 38,39 . Nevertheless, the low activity of exo-type alginate lyases is still the rate-limiting step for obtaining unsaturated monosaccharides. Therefore, obtaining exo-type alginate lyases capable of the highly efficient production of unsaturated monosaccharides would be a critical step toward simplifying the construction of engineered strains and promoting the process of industrialization.

In this study, an exo-type PL7 alginate lyase, VxAly7D, from the marine bacterium Vibrio xiamenensis QY104 was cloned and characterized. Recombinant VxAly7D efficiently degraded sodium alginate to produce unsaturated monosaccharides at low/moderate temperatures, providing a potentially excellent enzymatic tool for obtaining DEH. In addition, we verified the mechanism of its exo-type action mode, promoting the understanding of the relationship between the structure and function of alginate lyases and enriching the diversity of marine polysaccharide lyases.

\section{Results}

\section{Cloning and sequence analysis of VxAly7D}

The genomic sequence analysis of V.xiamenensis QY104, an efficient alginate-degrading marine bacterium, revealed six alginate lyase-encoding genes. Four of them belong to the PL7 family, and two belong to the PL17 family. Among these genes, the vxaly7D gene is $1041 \mathrm{bp}$ in length and encodes a protein of 346 amino acid residues, including a signal peptide of 19 amino acid residues at the $\mathrm{N}$-terminus. Mature VxAly7D has a calculated molecular mass of $36.46 \mathrm{kDa}$ and a theoretical $p I$ of 5.55 . According to sequence analysis using BLASTp, VxAly7D showed the highest identity $(72.54 \%)$ to the characterized PL7 alginate lyase AlyD from $V$. splendidus 12B01. VxAly7D formed a deeply branched cluster with PL7 alginate lyases in the phylogenetic tree (Fig. 1a). Moreover, the alignment of the amino acid sequence of mature VxAly7D with PL7 alginate lyases that had available resolved crystal structures showed that VxAly7D exhibits three highly conserved regions of the PL7 family [40, 41]: $\mathrm{R}(\mathrm{T} / \mathrm{S} / \mathrm{C} / \mathrm{V}) \mathrm{EL}(\mathrm{G} / \mathrm{R})(\mathrm{E} / \mathrm{Q})$, YFKAGXYXQ, and $\mathrm{Q}(\mathrm{I} / \mathrm{V}) \mathrm{H}$ (Fig. 1b). Based on the above analysis, VxAly7D was classified into the PL7 family.

Heterologous expression and biochemical characterization Recombinant VxAly7D without the predicted signal peptide was heterologously expressed in Escherichia coli. The purified recombinant enzyme showed 

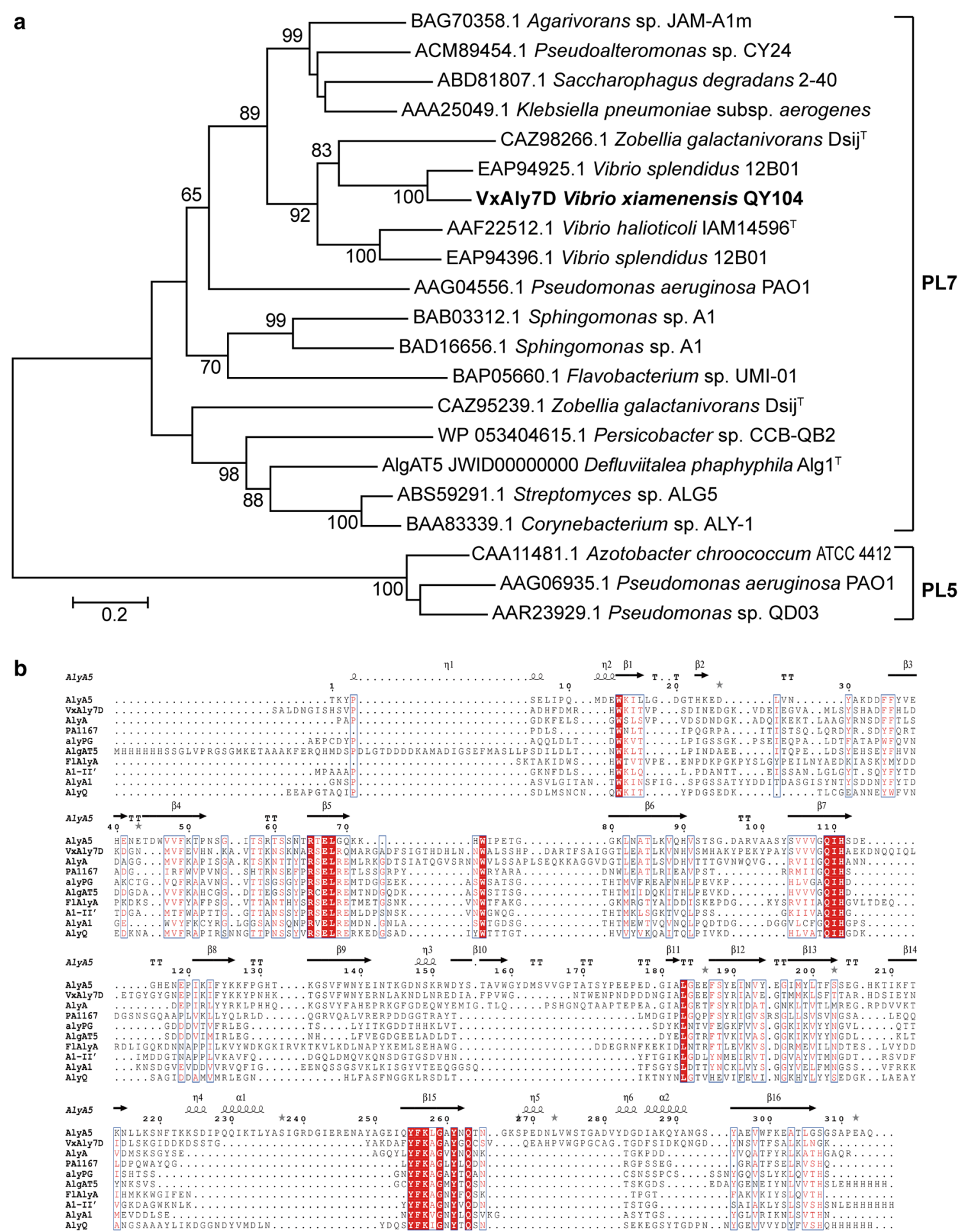

Fig. 1 Phylogenetic analysis and multiple amino acid sequence alignment of VxAly7D. a Phylogenetic analysis of VxAly7D. The phylogenetic tree was constructed with MEGA 7.0 using the neighbour-joining method. Bootstrap values were expressed based on 1000 replications, the numbers represent bootstrap values (confidence limits) representing the substitution frequencies per amino acid residue, and only values of $70 \%$ or above are shown at the nodes. The sequences from this study are shown in bold. $\mathbf{b}$ Multiple amino acid sequence alignment of $V x A l y 7 D$ with crystallized PL7 enzymes. The secondary structure elements shown above are referenced according to AlyA5. AlyA5, from Zobellia galactanivorans Dsij ${ }^{\top}$ (CAZ98266.1); AlyA, from Klebsiella pneumoniae (AAA25049); PA1167, from Pseudomonas aeruginosa PAO1 (AAG04556); alyPG, from Corynebacterium sp. ALY-1 (BAA83339); AlgAT5 from Defluviitalea phaphyphila Alg1 1' (JWID00000000); FlAlyA from Flavobacterium sp. UMI-01 (BAP05660); A1-II', from Sphingomonas sp. A1 (BAD16656); AlyA1, from Z. galactanivorans DsiJ' (CAZ95239); AlyQ from Persicobacter sp. CCB-QB2 (WP_053404615) 
a single band in SDS-PAGE gels with a molecular mass of approximately $36 \mathrm{kDa}$ (Fig. 2a). The activity of recombinant VxAly7D was measured at different $\mathrm{pH}$ values (3.0-10.6). Its optimum $\mathrm{pH}$ was 7.3 in $\mathrm{Na}_{2} \mathrm{HPO}_{4}-\mathrm{NaH}_{2} \mathrm{PO}_{4}$ buffer (PB) (Fig. 2b). The pH stability test for recombinant VxAly7D showed that the enzyme was stable at $\mathrm{pH} 4.6-10.0$, since more than $50 \%$ of its activity was retained (Fig. 2c), indicating that recombinant VxAly7D showed broad $\mathrm{pH}$ stability. The activity of recombinant VxAly7D was measured at different temperatures $\left(0-60{ }^{\circ} \mathrm{C}\right)$, and the maximum activity was observed at $30{ }^{\circ} \mathrm{C}$ (Fig. 2d). Recombinant VxAly7D exhibited $21 \%, 46 \%$, and $90 \%$ of its highest activity at 0,10 and $20{ }^{\circ} \mathrm{C}$, respectively. Recombinant VxAly7D lost most (92\%) of its activity after incubation at $40{ }^{\circ} \mathrm{C}$ for $1 \mathrm{~h}$; however, it was stable at $0-30{ }^{\circ} \mathrm{C}$, retaining approximately $80 \%$ of its enzyme activity after incubation for $1 \mathrm{~h}$ (Fig. 2d). Recombinant VxAly7D still retained $88 \%$ of its enzyme activity after incubation for $24 \mathrm{~h}$ at $20{ }^{\circ} \mathrm{C}$ and $55 \%$ of its enzyme activity after incubation for $15 \mathrm{~h}$ at $30{ }^{\circ} \mathrm{C}$ (Fig. 2e). And the half-life of recombinant VxAly7D was approximately $17 \mathrm{~h}$ at $30^{\circ} \mathrm{C}$ (Fig. 2e). These results indicated that recombinant VxAly7D presented high activity and stability at low/ moderate temperatures.
Recombinant VxAly7D did not require $\mathrm{NaCl}$ for enzymatic activity; however, the addition of $\mathrm{NaCl}$ significantly enhanced its activity. Recombinant VxAly7D was most active in the presence of $100 \mathrm{mM} \mathrm{NaCl}$ (Fig. 2f). The effects of other metal ions, ethylenediaminetetraacetic acid (EDTA), ethylenebis (oxyethylenenitrilo) tetraacetic acid (EGTA), dithiothreitol (DTT) and sodium dodecyl sulfate (SDS) on recombinant VxAly7D activity were also tested. $\mathrm{Li}^{+}, \mathrm{NH}_{4}{ }^{+}, \mathrm{Mg}^{2+}, \mathrm{Ba}^{2+}, \mathrm{Ca}^{2+}, \mathrm{Mn}^{2+}$, and $\mathrm{Fe}^{2+}$ could promote its activity, while the other metal ions $\left(\mathrm{Zn}^{2+}, \mathrm{Ni}^{2+}, \mathrm{Cu}^{2+}, \mathrm{Fe}^{3+}\right)$, as well as EDTA, EGTA, DTT and SDS inhibited its activity (Table 1).

Moreover, the specific activities of recombinant VxAly7D towards sodium alginate, polyG and polyM were $462.4 \pm 0.64, \quad 357.37 \pm 0.53$, and $441.94 \pm 2.46 \mathrm{U} / \mathrm{mg}$, respectively (Fig. 2g), indicating that this enzyme is a bifunctional alginate lyase. Broad substrate adaptability overcomes the limitations of available substrates and facilitates the preparation of monosaccharides.

\section{End products and action mode of recombinant VxAly7D}

The end products of recombinant VxAly7D were prepared by exhaustive degradation with excessive enzyme activity (20 $\mathrm{U}$ or $100 \mathrm{U}$ recombinant VxAly7D against $3 \mathrm{mg}$ sodium alginate at $30^{\circ} \mathrm{C}$ for $16 \mathrm{~h}$ ), analysed by TLC

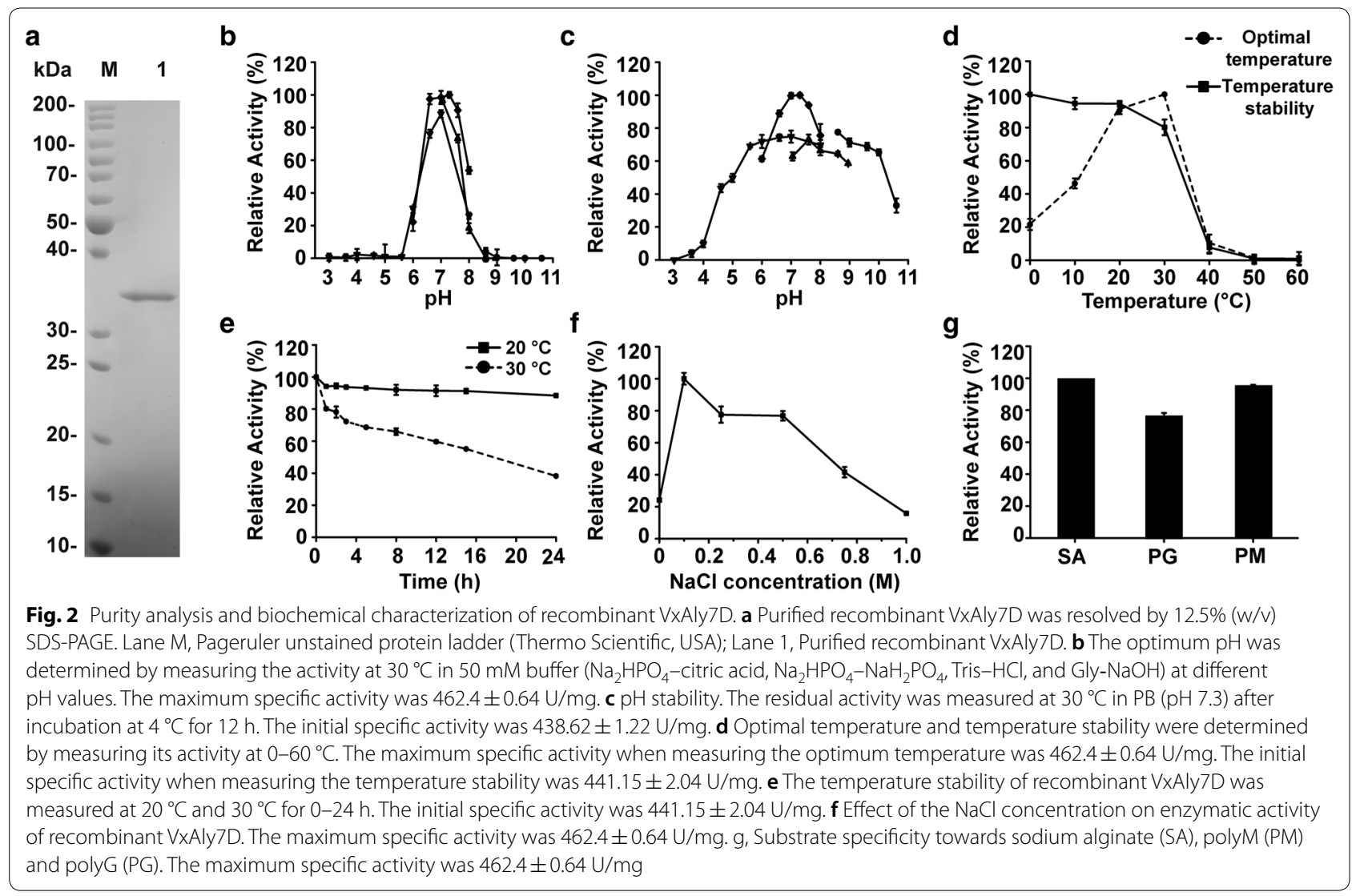


Table 1 Effect of metal ions, chelators, and detergents on recombinant $V x A l y 7 D$ activity

\begin{tabular}{llc}
\hline Reagents added & Concentration & Relative activity (\%) \\
\hline None & $0 \mathrm{mM}$ & $100.00 \pm 2.03$ \\
$\mathrm{LiCl}$ & $1 \mathrm{mM}$ & $147.17 \pm 2.83$ \\
$\mathrm{NH}_{4} \mathrm{Cl}$ & $1 \mathrm{mM}$ & $156.35 \pm 5.23$ \\
$\mathrm{MgCl}_{2}$ & $1 \mathrm{mM}$ & $108.27 \pm 2.50$ \\
$\mathrm{CaCl}_{2}$ & $1 \mathrm{mM}$ & $215.14 \pm 6.92$ \\
$\mathrm{MnCl}_{2}$ & $1 \mathrm{mM}$ & $145.73 \pm 4.01$ \\
$\mathrm{FeSO}_{4}$ & $1 \mathrm{mM}$ & $144.68 \pm 3.10$ \\
$\mathrm{NiCl}_{2}$ & $1 \mathrm{mM}$ & $65.03 \pm 0.98$ \\
$\mathrm{CuSO}_{4}$ & $1 \mathrm{mM}$ & $6.48 \pm 2.04$ \\
$\mathrm{ZnCl}_{2}$ & $1 \mathrm{mM}$ & $25.13 \pm 3.10$ \\
$\mathrm{BaCl}_{2}$ & $1 \mathrm{mM}$ & $130.19 \pm 5.28$ \\
$\mathrm{FeCl}_{3}$ & $1 \mathrm{mM}$ & $61.03 \pm 1.29$ \\
$\mathrm{EDTA}$ & $1 \mathrm{mM}$ & $21.20 \pm 1.05$ \\
$\mathrm{EGTA}$ & $1 \mathrm{mM}$ & $49.55 \pm 1.67$ \\
$\mathrm{DTT}$ & $1 \mathrm{mM}$ & $71.77 \pm 1.03$ \\
$\mathrm{SDS}$ & $3 \%$ & $2.40 \pm 0.23$ \\
\hline
\end{tabular}

and gel filtration chromatography, and identified by negative ion ESI-MS. According to the TLC results, the end products of $20 \mathrm{U}$ and $100 \mathrm{U}$ of recombinant VxAly7D were similar, mainly consisting of monosaccharides with small amounts of di- and trisaccharides (Fig. 3a). The end products of $20 \mathrm{U}$ of recombinant VxAly7D were also analysed by gel filtration chromatography. Sodium alginate was degraded into unsaturated monosaccharides (elution volume of $17.09 \mathrm{ml}$ ), unsaturated disaccharides (elution volume of $16.10 \mathrm{ml}$ ) and unsaturated trisaccharides (elution volume at $14.90 \mathrm{ml}$ ) (Fig. 3b). The contents of unsaturated di- and trisaccharides accounted for approximately $5 \%$ of the end products. However, some unsaturated monosaccharides could be converted to $\mathrm{DEH}$, which does not show absorption at $235 \mathrm{~nm}$. Thus, the monosaccharide content constituted not lower than $95 \%$ of the total end products. The end products of recombinant VxAly7D were further confirmed by negative ion ESI-MS to be unsaturated monosaccharides $(\triangle \mathrm{DP} 1)\left([\mathrm{M}-\mathrm{H}]^{-}=175.03\right)$, saturated monosaccharides (DP1) $\left([\mathrm{M}-\mathrm{H}]^{-}=193.04\right)$, unsaturated disaccharides $(\triangle \mathrm{DP} 2)\left([\mathrm{M}-\mathrm{H}]^{-}=351.06\right)$ and unsaturated trisaccharides $(\triangle \mathrm{DP} 3)\left([\mathrm{M}-\mathrm{H}]^{-}=527.09\right) \quad$ (Fig. 3c, Additional file 1: Fig. S1a). Moreover, each peak generated in gel filtration chromatography was collected separately, and its molecular weight was identified by negative ion ESI-MS (Additional file 1: Fig. S1b-d).

To determine the minimal degradation substrate of recombinant VxAly7D, recombinant VxAly7D activity towards different oligomannuronates with defined
DPs (dimannuronate-pentamannuronate: M2-M5) was measured. Recombinant VxAly7D exhibited no activity towards M2 and presented very weak activity towards M3, with specific activity of $1.32 \pm 0.32 \mathrm{U} /$ $\mathrm{mg}$. When the DP of the substrate increased from three to four, the specific activity of recombinant VxAly7D increased to $221 \pm 1.36 \mathrm{U} / \mathrm{mg}$ (Fig. 3d). The specific activity of recombinant VxAly7D towards M5 was $282.88 \pm 2.99 \mathrm{U} / \mathrm{mg}$ (Fig. 3d). The above results indicated that the minimal degradation substrate of recombinant VxAly7D was a tetrasaccharide.

According to the product distribution, recombinant VxAly7D seemed to degrade the substrate via the endo-type action mode to produce oligosaccharides with different DPs; however, the monosaccharide content of the product $(\geq 95 \%)$ seemed to contradict this speculation. To determine the action mode of recombinant VxAly7D, the viscosity and the absorbance at $235 \mathrm{~nm}$ of the reaction mixtures were measured during the enzymatic degradation of high-viscosity sodium alginate. The results showed that $\mathrm{A}_{235}$ increased throughout the entire degradation process (Fig. 4a), which indicated that recombinant VxAly7D could continuously degrade sodium alginate to produce unsaturated products. However, the viscosity of the reaction mixture decreased slowly and remained at $85 \%$ until 60 min (Fig. 4a), which suggested that recombinant VxAly7D degraded sodium alginate via an exo-type action mode. When the recombinant VxAly7D was incubated with sodium alginate, the absorption curve at $235 \mathrm{~nm}$ showed a kinetic in two phases (Fig. 4b). In the first phase, the absorption increased since sodium alginate was degraded by recombinant VxAly7D using $\beta$-elimination mechanism. Then the absorption gradually decreased, suggesting the reaction products spontaneously converted to $\mathrm{DEH}$, which did not show absorption at $235 \mathrm{~nm}$. This kinetic change in $\mathrm{A}_{235}$ is a typical feature of substrate degradation by exo-type alginate lyase [18]. Moreover, TLC analysis was also used to confirm this conclusion. The time-course analysis of the reaction products showed that monosaccharides and small amounts of di- and trisaccharides were produced from the beginning to the end of the reaction, and no oligosaccharides with other DPs were generated (Fig. 4c). This result also indicated that recombinant VxAly7D is an exo-type alginate lyase.

The above results indicated that recombinant VxAly7D degrades the substrate from the nonreducing end via an exo-type action mode, but cannot degrade oligosaccharides with the DP $<4$. Therefore, the end products of recombinant VxAly7D were mostly categorized as $\triangle \mathrm{DP} 1$ with a small amount of DP1, $\triangle \mathrm{DP} 2$ and $\triangle \mathrm{DP} 3$. 
a

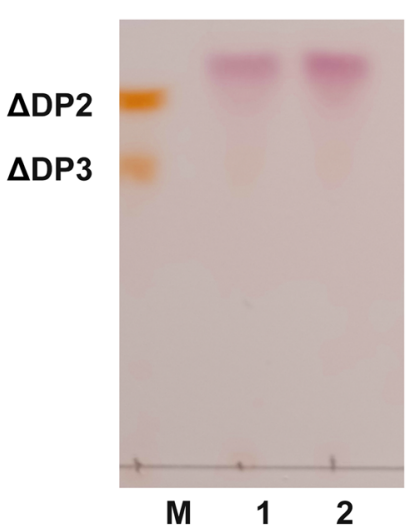

C $[\Delta \mathrm{DP} 1-\mathrm{H}]$

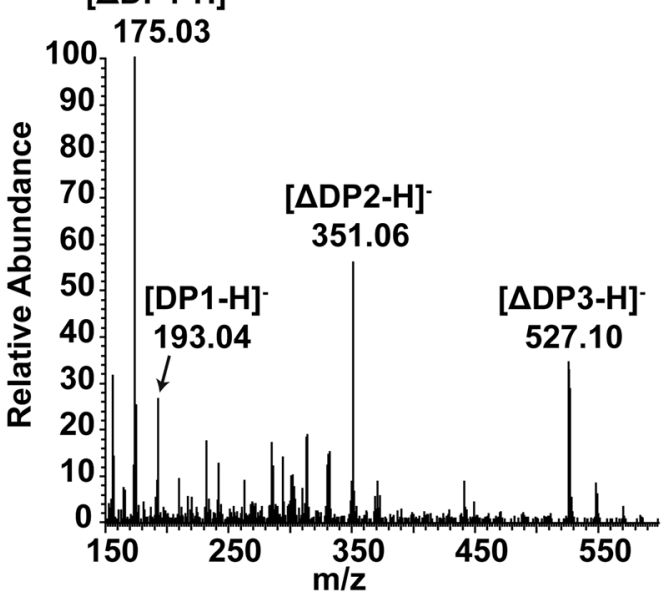

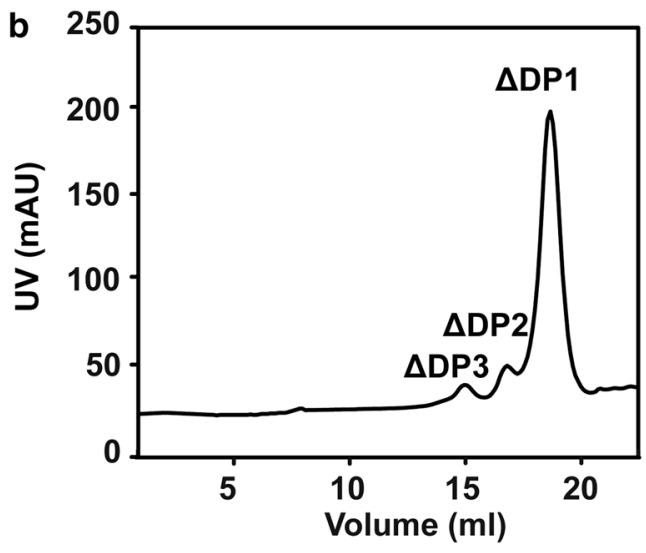

d

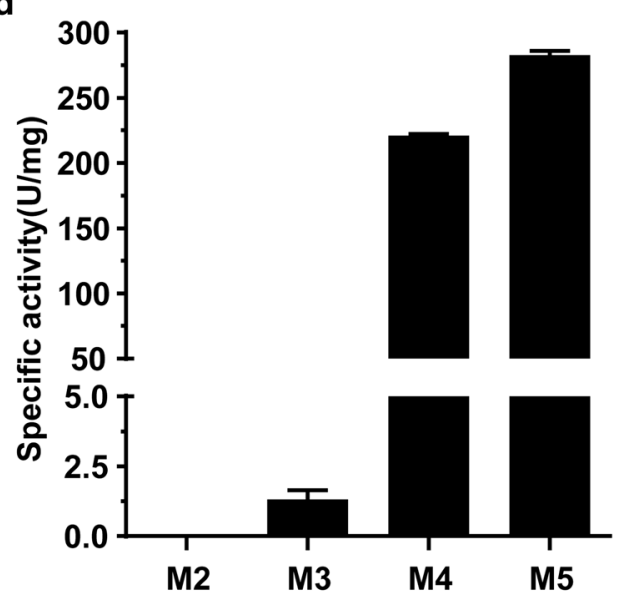

Fig. 3 End products and minimal degradation substrate of recombinant $V x A l y 7 D$. a TLC analysis of the end products of recombinant $V x A l y 7 D$. Lane $\mathrm{M}, \triangle \mathrm{DP} 2$ and $\triangle \mathrm{DP} 3$; Lane 1 and Lane 2 represent the end products of sodium alginate $(3 \mathrm{mg})$ degraded by $20 \mathrm{U}$ or $100 \mathrm{U}$ recombinant VxAly7D, respectively. $\mathbf{b}$ The end products of sodium alginate were analysed by gel filtration chromatography. Action of $20 \mathrm{U}$ recombinant $\mathrm{VxAly} 7 \mathrm{D}$ on $3 \mathrm{mg}$ sodium alginate at $30^{\circ} \mathrm{C}$ for $16 \mathrm{~h}$. The elution volumes were $17.09 \mathrm{ml}$ for monosaccharides, $16.10 \mathrm{ml}$ for disaccharides, and $14.90 \mathrm{ml}$ for trisaccharides. $\mathbf{c}$ The end products of sodium alginate were analysed by negative ion ESI-MS. $\mathbf{d}$ Relative activities of recombinant VxAly7D towards M2-M5

\section{Enzymatic preparation of unsaturated alginate} monosaccharide with recombinant VxAly7D

To determine the minimal amount of recombinant VxAly7D capable of rapidly and completely degrading sodium alginate, sodium alginate $(3 \mathrm{mg} / \mathrm{ml})$ was digested using recombinant VxAly7D at different concentrations $(0,1$, $2,6,10$, and $20 \mathrm{U} / \mathrm{ml}$ ) at the corresponding optimal temperature for $1 \mathrm{~h}$. Each enzymatic product $(\sim 3 \mathrm{mg})$ was analysed with a Superdex peptide 10/300 GL column and monitored at $235 \mathrm{~nm}$. The results showed that $1 \mathrm{U} /$ $\mathrm{ml}$ recombinant VxAly7D could weakly degrade sodium alginate, and $2 \mathrm{U} / \mathrm{ml}$ converted $30 \%$ of the substrate into unsaturated oligosaccharides (Fig. 5a). Furthermore, the end products of sodium alginate degraded using 6,10 , or $20 \mathrm{U} / \mathrm{ml}$ recombinant VxAly7D were similar (Figs. 3b,
$5 \mathrm{a})$, indicating that $13 \mu \mathrm{g}(=6 \mathrm{U})$ recombinant VxAly7D could convert $3 \mathrm{mg}$ sodium alginate into unsaturated monosaccharides with a yield of $95 \%$ in $1 \mathrm{~h}$.

To determine the unsaturated monosaccharide production rate by recombinant VxAly7D, a time-course analysis of sodium alginate degradation was carried out. Sodium alginate $(3 \mathrm{mg} / \mathrm{ml})$ was digested using $6 \mathrm{U} / \mathrm{ml}$ recombinant VxAly7D for $0-60 \mathrm{~min}$, and the resultant products were collected at $0,1,5,10,20,30,40$ and $60 \mathrm{~min}$ and analysed by gel filtration chromatography. The amount of the products gradually increased as time increased. The contents of unsaturated monosaccharides in the end products at $1,5,10,20,30$ and 40 min were $37.6 \%, 47.2 \%$, $59.2 \%, 76.6 \%$ and $85 \%$, respectively (Fig. 5b). Thus, the above results indicated that recombinant VxAly7D could 

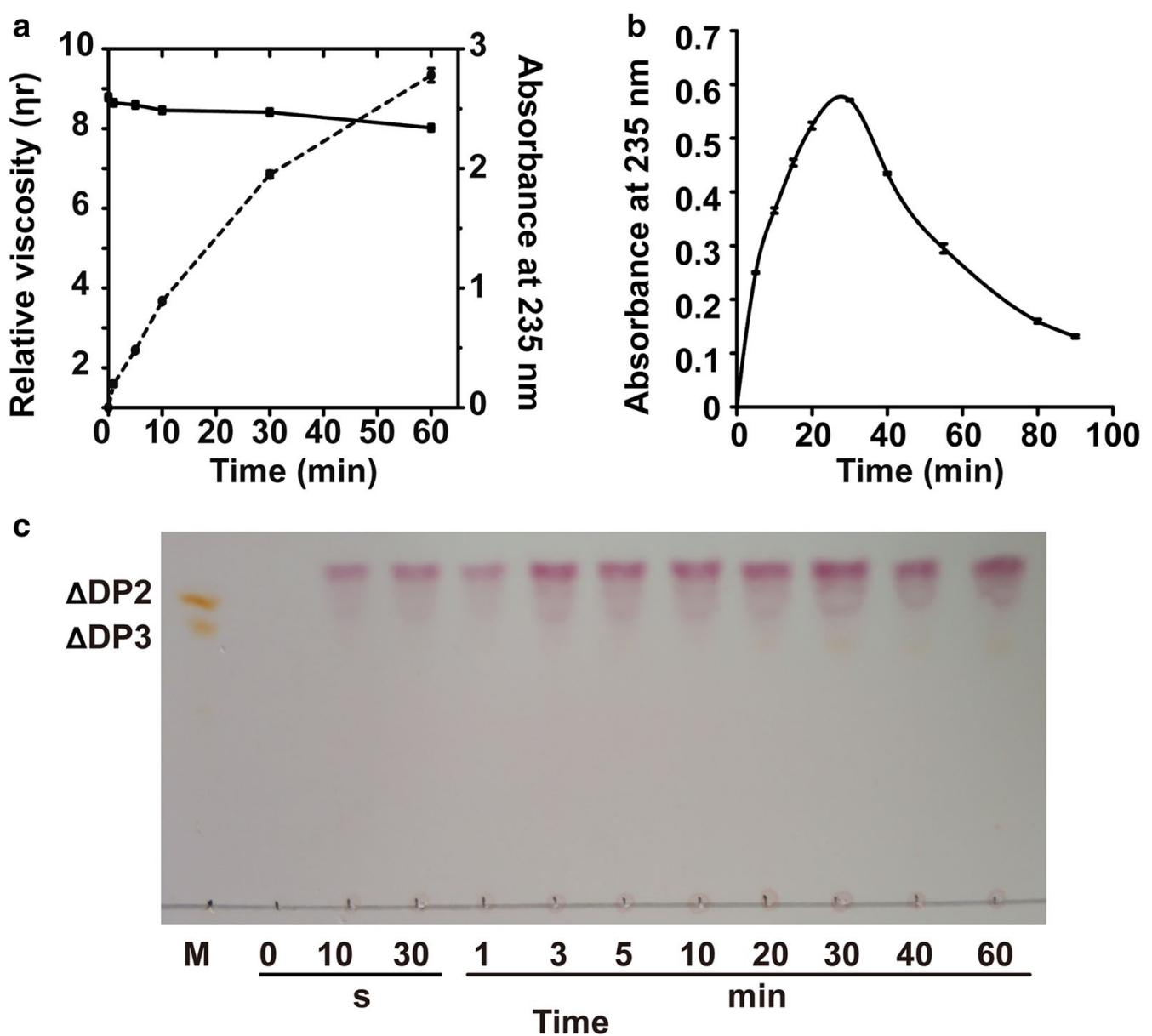

Fig. 4 Action mode of recombinant VxAly7D. a The action mode was measured according to the changes in absorbance at $235 \mathrm{~nm}$ (dotted line) and reduction in viscosity (solid line). One millilitre of enzyme (10 U) was added to $9 \mathrm{ml}$ of substrate solution $[0.3 \%$ (w/v) high-viscosity sodium alginate, $100 \mathrm{mM} \mathrm{NaCl}, 20 \mathrm{mM} \mathrm{PB}$, optimal pH], followed by incubation at $30^{\circ} \mathrm{C}$ for 0, 1, 5, 10, 30 and $60 \mathrm{~min}$. b The time-dependent changes in absorbance at $235 \mathrm{~nm}$ of reaction mixtures by recombinant VxAly7D. A total of $12 \mathrm{U}$ enzyme was added to $1 \mathrm{ml}$ substrate solution [0.3\% (w/v) sodium alginate, $100 \mathrm{mM} \mathrm{NaCl}, 20 \mathrm{mM} \mathrm{PB}$, optimal pH], followed by incubation at $30^{\circ} \mathrm{C}$ for 0, 5, 15, 20, 30, 40, 55, 80 and 90 min. c The time-course of sodium alginate degradation by recombinant $V x A l y 7 D$ was determined by TLC. A total of $5 \mathrm{U}$ enzyme was added to $1 \mathrm{ml}$ substrate solution [0.3\% (w/v) sodium alginate, $100 \mathrm{mM} \mathrm{NaCl}, 20 \mathrm{mM} \mathrm{PB}$, optimal pH], followed by incubation at $30^{\circ} \mathrm{C}$ for $0 \mathrm{~s}, 10 \mathrm{~s}, 30 \mathrm{~s}, 1 \mathrm{~min}, 3 \mathrm{~min}, 5 \mathrm{~min}, 10 \mathrm{~min}, 20 \mathrm{~min}$, $30 \mathrm{~min}, 40 \mathrm{~min}$, or $60 \mathrm{~min}$

be used to rapidly and highly efficiently degrade sodium alginate and produce unsaturated monosaccharides.

\section{Homology modelling and structure alignment of VxAly7D}

Among the crystallized PL7 alginate lyases, the VxAly7D showed the highest identity (39.71\%) with that of AlyA5 from Zobellia galactanivorans $\mathrm{Dsij}^{\mathrm{T}}$. The structure of VxAly7D was obtained by homologous modelling using AlyA5. VxAly7D has a typical $\beta$-jelly roll structure that conforms to the structural features of the PL7 alginate lyases (Fig. 6a). The structure quality of VxAly7D was evaluated by Verify3D [42]. Verify $3 \mathrm{D}$ results show that $92.45 \%$ of the residues have averaged 3D-1D score of no less than 0.2. Therefore, the structure of VxAly7D constructed by homology modelling is reasonable. The comparison of the structures of the exo-type alginate lyases AlyA5, VxAly7D, and the endo-type alginate lyase A1-II' from Sphingomonas sp. A1 showed that AlyA5 and VxAly7D both exhibit three additional loops (loop1, loop2, and loop3), while A1-II' does not. However, while loop3 of VxAly7D is consistent with loop3 of AlyA5, loop1 and loop2 of VxAly7D are significantly shorter than loop1 and loop2 of AlyA5. According to previous reports, loop3 might be the critical loop responsible for the action mode of exo-type PL7 alginate lyase [43], in which Trp ${ }^{295}$ of VxAly7D (which corresponds to $\operatorname{Trp}^{313}$ of AlyA5) might be a critical amino acid residue because it constitutes 

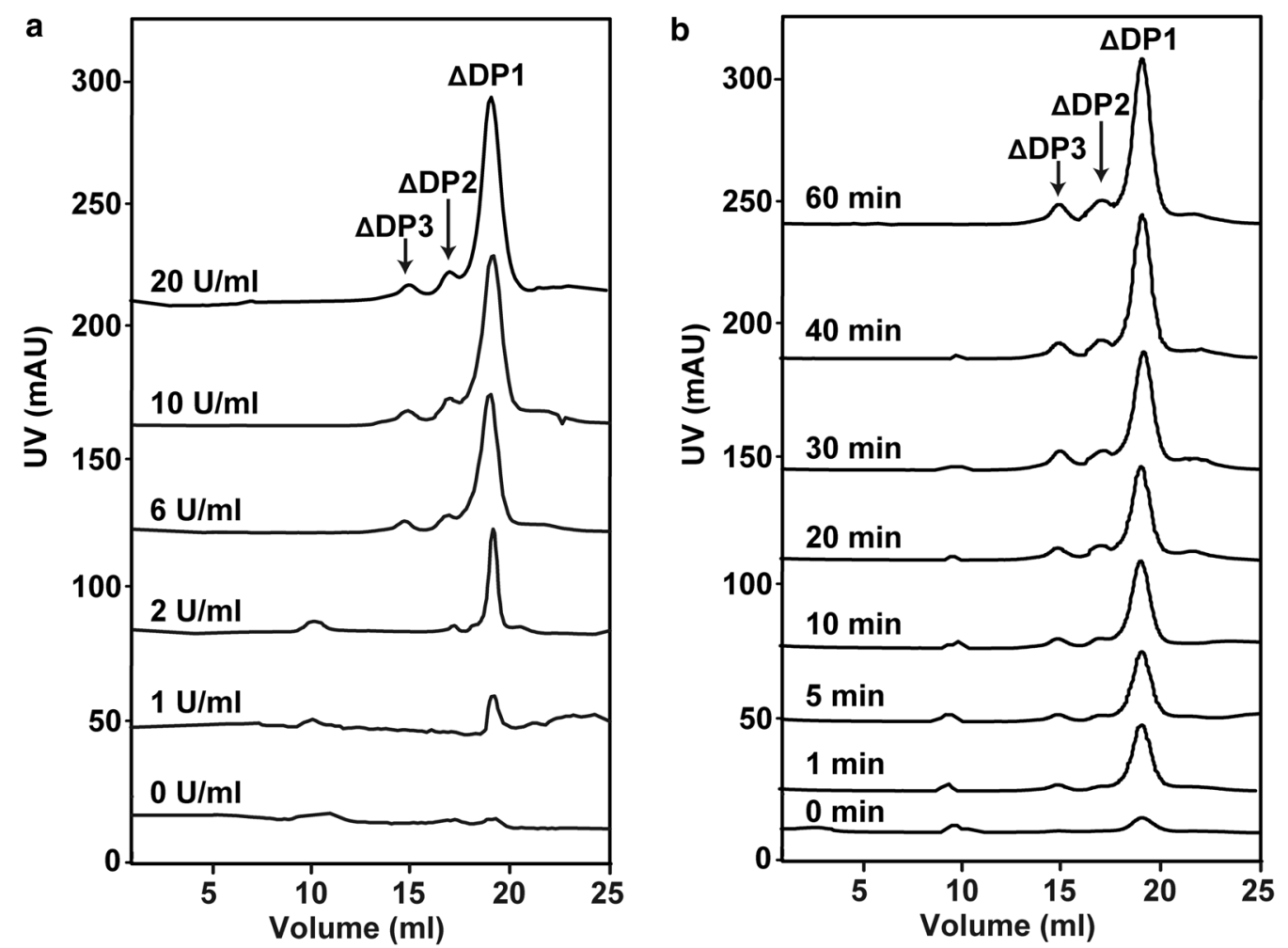

Fig. 5 Enzymatic degradation rate of sodium alginate by recombinant VxAly7D. a Products of sodium alginate (3 mg/ml) degraded by different amounts $(0,1,2,6,10,20 \mathrm{U} / \mathrm{ml})$ of recombinant $V x$ Aly $7 \mathrm{D}$ for $1 \mathrm{~h}$. b Time-course treatment of sodium alginate $(3 \mathrm{mg} / \mathrm{ml}) \mathrm{using} 6 \mathrm{U} / \mathrm{ml}$ recombinant VxAly7D at $30^{\circ} \mathrm{C}$ for $0,1,5,10,20,30,40$ and 60 min

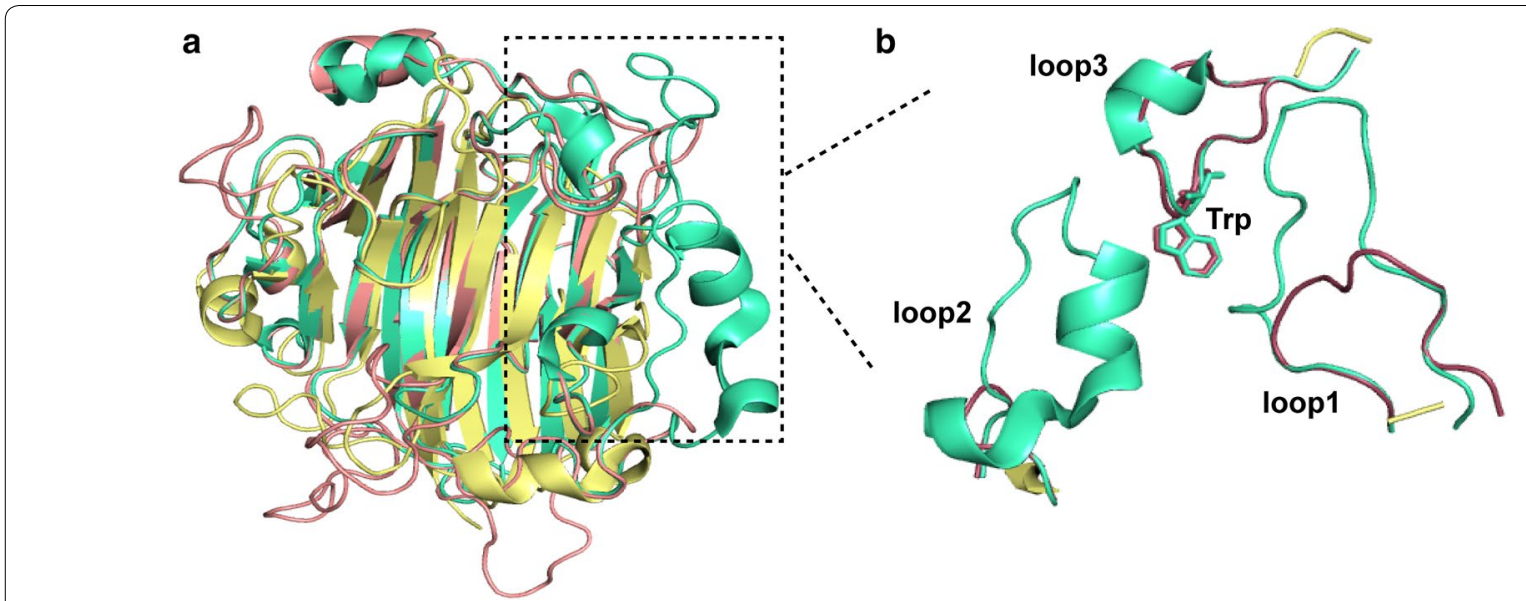

Fig. 6 Homology modelling of VxAly7D. a The structures of VxAly7D, AlyA5 (PDB ID: 4BE3) and A1-II' (PDB ID: 2CWS) were performed using PyMOL. VxAly7D, red cartoon; AlyA5, green cartoon; A1-II', yellow cartoon. b Three extra loops of VxAly7D 
a hydrophobic wall obstructing the continuation of the groove [18] (Fig. 6b).

\section{Construction, purification and biochemical characterization of mutants}

According to structural analysis, two mutants, CL3 (loop3-deletion mutant) and W295A (site-directed mutant), were constructed. The purified W295A mutant showed a single band in SDS-PAGE gels with a molecular mass of approximately $36 \mathrm{kDa}$, as observed for recombinant VxAly7D (Additional file 1: Fig. S2a). The specific activity of purified W295A towards sodium alginate was $74.09 \pm 1.53 \mathrm{U} / \mathrm{mg}$, while purified CL3 exhibited almost no activity. The above results indicated that loop3 and $\operatorname{Trp}^{295}$ affect the catalysis of the substrate by recombinant VxAly7D.

The biochemical characterization of the W295A mutant was determined. Its optimum $\mathrm{pH}$ was 6.6 in PB (Additional file 1: Fig. S2b). The pH stability of the W295A mutant showed that the enzyme was stable at a $\mathrm{pH}$ of $6.6-8.0$, since approximately $50 \%$ of its activity was retained (Additional file 1: Fig. S2c). Compared with other buffers, the W295A mutant retained higher activity and stability in PB buffer. However, compared with recombinant VxAly7D, the W295A mutant exhibited lower $\mathrm{pH}$ stability (Fig. 2c, Additional file 1: Fig. S2c). The optimum temperature of the W295A mutant was $30{ }^{\circ} \mathrm{C}$ (Additional file 1: Fig. S2d). The W295A mutant exhibited $13 \%, 33 \%$, and $85 \%$ of its highest activity at 0,10 and $20^{\circ} \mathrm{C}$, respectively. The W295A mutant was stable at $0-30{ }^{\circ} \mathrm{C}$, with approximately $80 \%$ of the enzyme activity retained after incubation for $1 \mathrm{~h}$ (Additional file 1: Fig. S2e). Similar to recombinant VxAly7D, the W295A mutant still exhibited high activity and stability at low/moderate temperatures $\left(0-30{ }^{\circ} \mathrm{C}\right)(\mathrm{Fig} .2 \mathrm{~d}$, Additional file 1: Fig. S2d, e). The effects of $\mathrm{NaCl}$ (Additional file 1: Fig. S2f), metal ions, surfactants (EDTA and EGTA), detergents (SDS) and reducing agents (DTT) on the activity of the W295A mutant were not significantly different from those of recombinant VxAly7D (Table 1, Additional file 1: Table S1). The substrate preference of the W295A mutant was also consistent with that of recombinant VxAly7D (Fig. 2g, Additional file 1: Fig. S2g). a

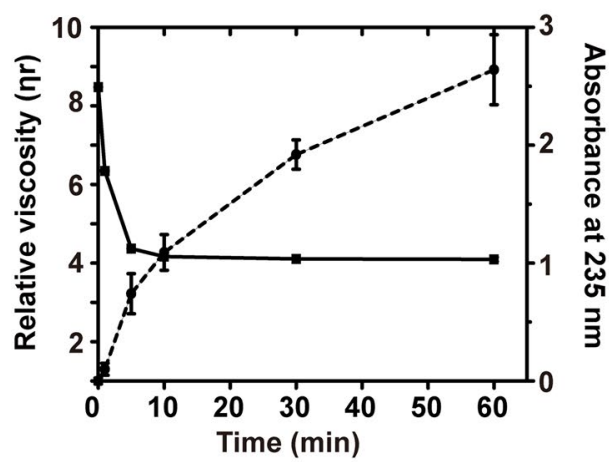

c

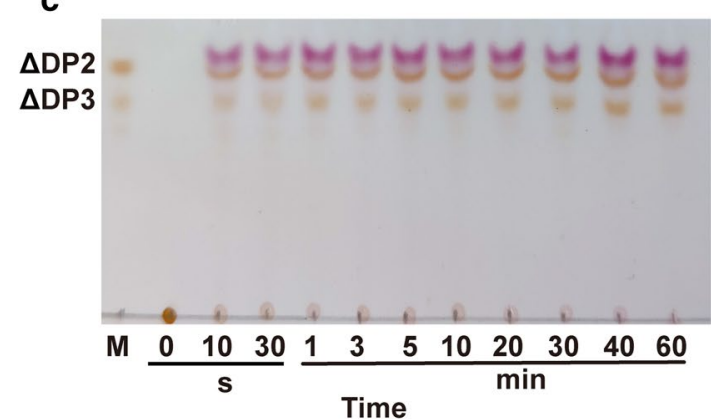

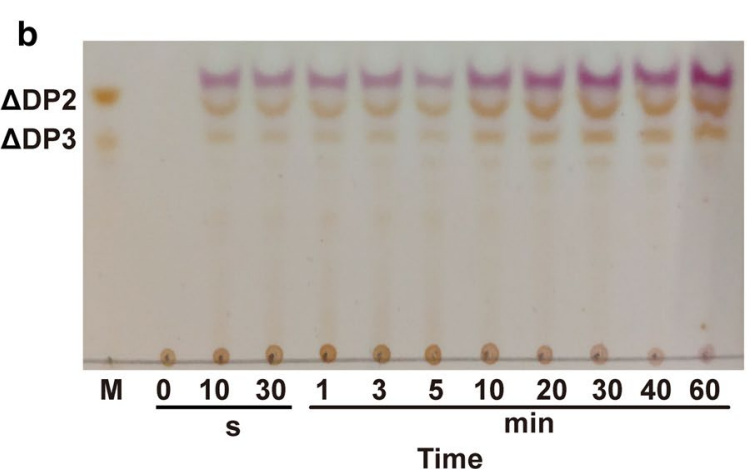

d

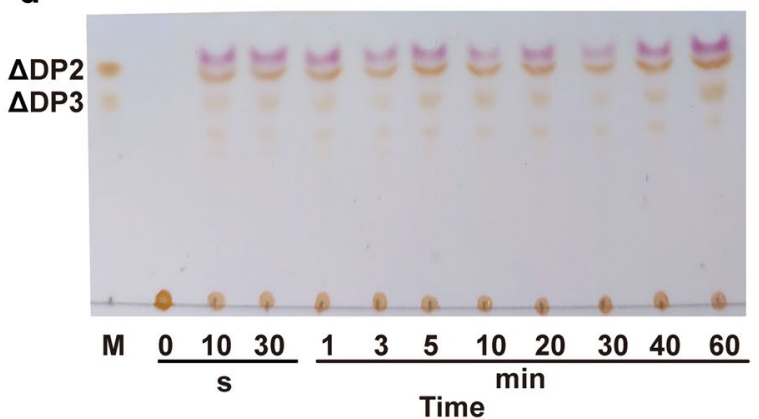

Fig. 7 Action mode of the W295A mutant. a The action mode was measured according to the changes in absorbance at $235 \mathrm{~nm}$ (dotted line) and the reduction in viscosity (solid line). One millilitre of enzyme $(10 \mathrm{U}$ ) was added to $9 \mathrm{ml}$ of substrate solution [0.3\% (w/v) high-viscosity sodium alginate, $100 \mathrm{mM} \mathrm{NaCl}, 20 \mathrm{mM} \mathrm{PB}$, optimal pH], followed by incubation at $30^{\circ} \mathrm{C}$ for 0, 1, 5, 10, 30 and $60 \mathrm{~min}$. $\mathbf{b}$ The time-course of sodium alginate degradation by the W295A mutant was determined by TLC. A total of $5 \mathrm{U}$ of enzyme were added to $1 \mathrm{ml}$ substrate solution [0.3\% (w/v) sodium alginate, $100 \mathrm{mM} \mathrm{NaCl}, 20 \mathrm{mM} \mathrm{PB}$, optimal pH], followed by incubation at $30^{\circ} \mathrm{C}$ for $0 \mathrm{~s}, 10 \mathrm{~s}, 30 \mathrm{~s}, 1 \mathrm{~min}, 3 \mathrm{~min}, 5 \mathrm{~min}, 10 \mathrm{~min}, 20 \mathrm{~min}, 30 \mathrm{~min}, 40 \mathrm{~min}$, or 60 min. c, d The time-course of polyM and polyG degradation by the W295A mutant were determined by TLC. A total of $3 \mathrm{U}$ of enzyme were added to $1 \mathrm{ml}$ substrate solution [0.3\% (w/v) polyM or polyG, $100 \mathrm{mM} \mathrm{NaCl}, 20 \mathrm{mM} \mathrm{PB}$, optimal pH], followed by incubation at $30^{\circ} \mathrm{C}$ for $0 \mathrm{~s}, 10 \mathrm{~s}, 30 \mathrm{~s}$, $1 \mathrm{~min}, 3 \mathrm{~min}, 5 \mathrm{~min}, 10 \mathrm{~min}, 20 \mathrm{~min}, 30 \mathrm{~min}, 40 \mathrm{~min}$, or $60 \mathrm{~min}$ 
Action mode and end products of the W295A mutant

We also determined the action mode and the end products of the W295A mutant. The results showed that $\mathrm{A}_{235}$ increased throughout the degradation process; however, viscosity decreased rapidly within the first $10 \mathrm{~min}$ and decreased slowly in the last 50 min (Fig. 7a), suggesting that the W295A mutant degraded sodium alginate in an endolytic action mode. We also use TLC to further validate the action mode of the W295A mutant. Analysis of the time-course of the reaction products showed that mono-, di-, and trisaccharides, and other oligosaccharides with low DPs were produced at the beginning of the reaction. With the prolongation of reaction time, the amounts of mono-, di- and trisaccharides gradually increased, while those of oligosaccharides with other
DPs significantly decreased (Fig. 7b-d). This distribution of the products indicated that the W295A mutant presented both exo- and endo-type action modes. The results showed that $\operatorname{Trp}^{295}$ was the key amino acid residue responsible for the exo-type action mode of recombinant VxAly7D.

According to the TLC analysis, the end products of sodium alginate obtained with $20 \mathrm{U}$ or $100 \mathrm{U}$ of the W295A mutant were similar, and both consisted of mono-, di- and trisaccharides (Fig. 8a). The end products of polyM and polyG were the same with sodium alginate (Additional file 1: Fig. S3). Based on the elution volume and peak areas of gel filtration chromatography, the end products of the W295A mutant were unsaturated mono-, di- and trisaccharides (Fig. 8b). The oligosaccharide

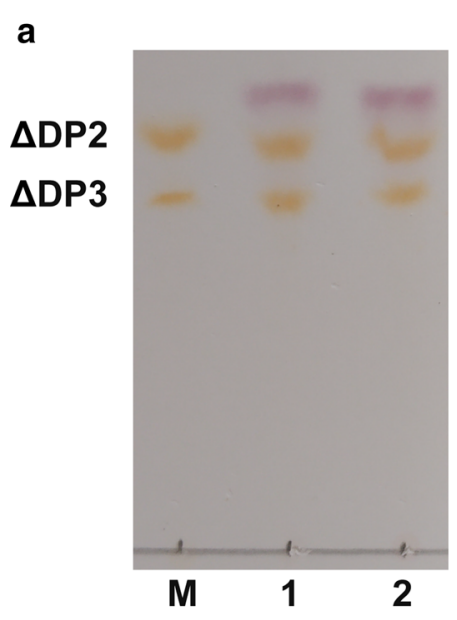

C
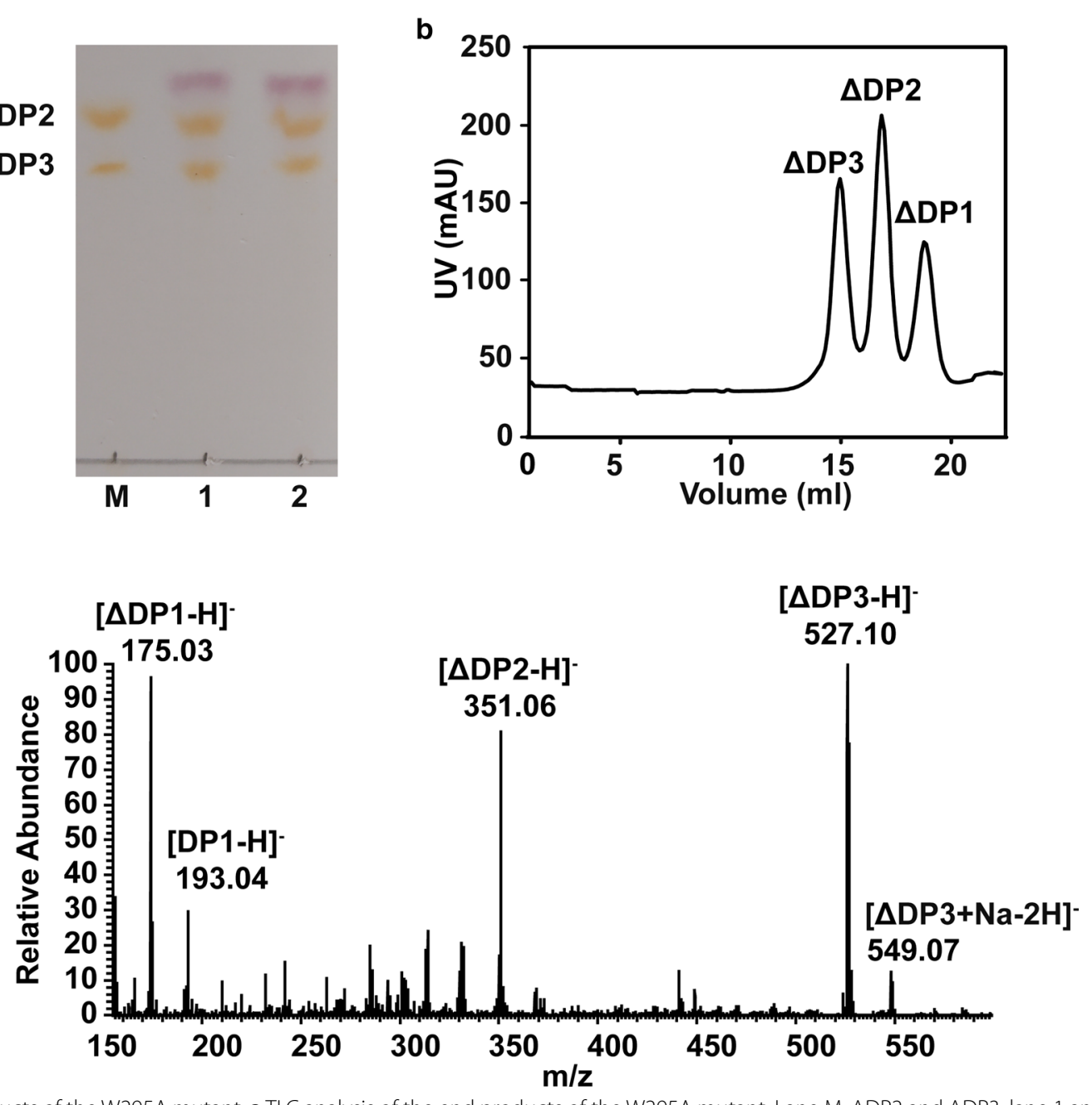

Fig. 8 End products of the W295A mutant. a TLC analysis of the end products of the W295A mutant. Lane M, $\triangle D P 2$ and $\triangle D P 3 ;$ lane 1 and lane 2 show the end products of sodium alginate $(3 \mathrm{mg}$ ) degraded by $20 \mathrm{U}$ or $100 \mathrm{U}$ of the W295A mutant, respectively. $\mathbf{b}$ The end products of the W295A mutant were analysed by gel filtration chromatography. Action of $20 \mathrm{U}$ of the W295A mutant against $3 \mathrm{mg}$ of sodium alginate at $30^{\circ} \mathrm{C}$ for $16 \mathrm{~h}$. C The end products of the W295A mutant were analysed by negative ion ESI-MS 
products of the W295A mutant were confirmed by negative ion ESI-MS to be $\triangle \mathrm{DP} 1\left([\mathrm{M}-\mathrm{H}]^{-}=175.03\right)$, DP1 $\left(\mathrm{M}-\mathrm{H}^{-}=193.04\right), \Delta \mathrm{DP} 2\left([\mathrm{M}-\mathrm{H}]^{-}=351.06\right)$ and $\Delta \mathrm{DP} 3$ $\left([\mathrm{M}-\mathrm{H}]^{-}=527.09\right)$ (Fig. 8c, Additional file 1: Fig. S4a). Each peak from the gel filtration chromatography analysis was collected separately, and its molecular weight was identified by negative ion ESI-MS (Additional file 1: Fig. S4b-d).

\section{Discussion}

Nearly half of known alginate lyase sequences have been classified into the PL7 family; however, exo-type PL7 alginate lyases have rarely been reported [18, 39, 44, 45]. In this paper, the exo-type PL7 alginate lyase VxAly7D from $V$. xiamenensis QY104 was cloned and characterized. VxAly7D showed the highest identity (72.54\%) to AlyD from $V$. splendidus 12B01. However, compared with AlyD [46], recombinant VxAly7D exhibited lower $\mathrm{NaCl}$ dependence and higher metal ion tolerance (Table 2). More importantly, recombinant VxAly7D showed different action mode than AlyD (Fig. 4, Table 2), since AlyD is an endo-type alginate lyase $[39,46]$. Both recombinant VxAly7D and AlyA5 from Zobellia galactanivorans Dsij ${ }^{\mathrm{T}}$ are exo-type alginate lyases [18] belonging to the PL7 family, which cleave the unit at the nonreducing end, but their end products are different. Trisaccharides, which are the minimal degradation substrate of AlyA5, are converted into monosaccharides as the major product and disaccharides as the minor product [18]. However, the minimal degradation substrate of recombinant VxAly7D was found to be tetrasaccharides, which were eventually turned into monosaccharides as the major product and di- and trisaccharides as the minor product (Fig. 3).
The above results showed that although VxAly7D shares high identity with AlyD and AlyA5 (Fig. 1a), their biochemical characterization is still significantly different. Furthermore, compared with alginate lyases of the PL7 family with high activity at low/moderate temperatures, recombinant VxAly7D did not exhibit a substrate preference and showed the highest percentage of its maximum activity at $20{ }^{\circ} \mathrm{C}$ (Table 3 ). The above results suggested that VxAly7D has specific characterization as an exo-type alginate lyase of the PL7 family.

Exo-type alginate lyases cleave the substrate from the ends of the chains [43], resulting in a low degradation rate and monosaccharide production [29-34, 46-49]. The specific activity of recombinant VxAly7D towards sodium alginate was $462.4 \pm 0.64 \mathrm{U} / \mathrm{mg}$, which was higher than that of other reported exo-type alginate lyases. Moreover, the unsaturated monosaccharide yield and production rate of recombinant VxAly7D were higher than those of other alginate lyases that function in an exolytic action mode. We found that $13 \mu \mathrm{g}$ recombinant VxAly7D converted $3 \mathrm{mg}$ sodium alginate to unsaturated monosaccharides with a yield of 95\% (Figs. 3b, 5a). Furthermore, gel filtration chromatography analysis showed that sodium alginate could be rapidly degraded to unsaturated monosaccharides with a yield of $37.6 \%$ within 1 min (Fig. 5b). The results showed that recombinant VxAly7D was an exo-type alginate lyase that can highly efficiently degrade sodium alginate to produce unsaturated monosaccharides. In addition, due to the low activity of reported exo-type alginate lyases, a method for applying the synergistic action of endo-type and exo-type alginate lyases was established to obtain a high yield of monosaccharides [4, 6, 38]. Alg7A/Alg7K

Table 2 Comparison of biochemical characterization of recombinant VxAly7D and AlyD

\begin{tabular}{|c|c|c|}
\hline Parameter & VxAly7D & AlyD \\
\hline Origin & V.xiamenensis QY104 & V.splendidus 12B01 \\
\hline Molecular mass & $36.46 \mathrm{kDa}$ & $36.5 \mathrm{kDa}$ \\
\hline Optimal pH & 7.3 & 8 \\
\hline Optimal temperature & $30^{\circ} \mathrm{C}$ & $20^{\circ} \mathrm{C}$ \\
\hline Optimal $\mathrm{NaCl}$ concentration & $100 \mathrm{mM}$ & $400 \mathrm{mM}$ \\
\hline \multicolumn{3}{|l|}{ Metal ions } \\
\hline Inhibition & $\mathrm{Cu}^{2+}, \mathrm{Ni}^{2+}, \mathrm{Zn}^{2+}$ & $\mathrm{Cu}^{2+}, \mathrm{Ni}^{2+}, \mathrm{Zn}^{2+}, \mathrm{Fe}^{2+}, \mathrm{Mg}^{2+}, \mathrm{Mn}^{2+}$ \\
\hline Promotion & $\mathrm{Ca}^{2+}, \mathrm{Fe}^{2+}, \mathrm{Mg}^{2+}, \mathrm{Mn}^{2+}$ & $\mathrm{Ca}^{2+}$ \\
\hline EDTA & Inhibit & Inhibit \\
\hline \multirow[t]{3}{*}{ Substrate preference } & Sodium alginate $(462.40 \mathrm{U} / \mathrm{mg})$ & Alginate $(0.5 \mu \mathrm{M} / \mathrm{s} / \mu \mathrm{g})$ \\
\hline & polyG (357.37 U/mg) & polyG $(0.41 \mu \mathrm{M} / \mathrm{s} \mu \mathrm{g})$ \\
\hline & polyM (441.94 U/mg) & 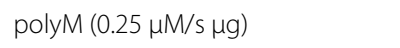 \\
\hline Products & Mono-, di-, trisaccharides & Mono-, di-, pentasaccharides \\
\hline Action mode & Exo-type & Endo-type \\
\hline Reference & In this study & {$[46]$} \\
\hline
\end{tabular}


Table 3 Comparison of recombinant VxAly7D with other alginate lyases

\begin{tabular}{|c|c|c|c|c|c|c|c|c|c|}
\hline Enzyme & Source & Family & $\begin{array}{l}\text { Specific } \\
\text { activity }\end{array}$ & $\begin{array}{l}\text { Optimal } \\
\text { temperature }\end{array}$ & $\begin{array}{l}\text { Percent } \\
\text { of the maximal } \\
\text { activity at } 20^{\circ} \mathrm{C} \\
(\%)\end{array}$ & Substrate specificity & $\begin{array}{l}\text { Products } \\
\text { (DP) }\end{array}$ & $\begin{array}{l}\text { Action } \\
\text { mode }\end{array}$ & References \\
\hline VxAly7D & $\begin{array}{l}\text { Vibrio xiamenensis } \\
\text { QY104 }\end{array}$ & PL7 & $\begin{array}{l}462.4 \mathrm{U} / \\
\mathrm{mg}\end{array}$ & 30 & 90 & $\begin{array}{l}\text { Sodium algi- } \\
\text { nate } \approx \text { polyM }>\text { polyG }\end{array}$ & $1-3$ & Exo-type & In this study \\
\hline AlyA5 & $\begin{array}{l}\text { Zobellia } \\
\text { galactanivorans } \\
\text { Dsij }\end{array}$ & PL7 & $\begin{array}{l}449.3 \mathrm{U} / \\
\mathrm{mg}\end{array}$ & 30 & No data & PolyG > polyMG > polyM & $1-2$ & Exo-type & [18] \\
\hline AlyPM & $\begin{array}{l}\text { Pseudoalte- } \\
\text { romonas sp. } \\
\text { SM0524 }\end{array}$ & PL7 & No data & 30 & 52 & $\begin{array}{l}\text { PolyM }>\text { sodium algi- } \\
\text { nate }>\text { polyG }\end{array}$ & $2-3$ & Endo-type & [16] \\
\hline Algb & Vibrio sp.W13 & PL7 & $457 \mathrm{U} / \mathrm{mg}$ & 30 & 80 & $\begin{array}{l}\text { Sodium alginate } \approx \text { pol- } \\
\text { yMG }>\text { polyG }>\text { polyM }\end{array}$ & $2-5$ & Endo-type & {$[62]$} \\
\hline AlyA $1_{\text {PL7 }}$ & $\begin{array}{l}\text { Zobellia } \\
\text { galactanivorans } \\
\text { Dsij }\end{array}$ & PL7 & No data & 30 & 82 & PolyG > polyM & $2-4$ & Endo-type & {$[18]$} \\
\hline TsAly6A & $\begin{array}{l}\text { Thalassomonas } \\
\text { sp. LD5 }\end{array}$ & PL6 & $189 \mathrm{U} / \mathrm{mg}$ & 35 & 73.1 & $\begin{array}{l}\text { PolyG } \approx \text { algi- } \\
\text { nate }>\text { polyM }\end{array}$ & $2-3$ & Endo-type & [14] \\
\hline AlyGC & $\begin{array}{l}\text { Glaciecola chatha- } \\
\text { mensis S18K6 }\end{array}$ & PL6 & $170 \mathrm{U} / \mathrm{mg}$ & 30 & 82.5 & $\begin{array}{l}\text { PolyG }>\text { polyM }>\text { sodium } \\
\text { alginate }\end{array}$ & 1 & Exo-type & [15] \\
\hline AkAly30 & Aplysia kurodai & PL14 & $210 \mathrm{U} / \mathrm{mg}$ & 55 & 20 & $\begin{array}{l}\text { PolyM > alginate > pol- } \\
\text { yMG > polyG }\end{array}$ & $1-3$ & $\begin{array}{l}\text { Endo- and } \\
\text { exo- } \\
\text { type }\end{array}$ & {$[63,64]$} \\
\hline A1-IV & $\begin{array}{l}\text { Sphingomonas } \\
\text { sp. A1 }\end{array}$ & PL15 & $7.5 \mathrm{U} / \mathrm{mg}^{\mathrm{a}}$ & 37 & No data & polyM $\approx$ polyG & 1 & Exo-type & {$[65]$} \\
\hline AlgL17 & $\begin{array}{l}\text { Microbulbifer sp. } \\
\text { ALW1 }\end{array}$ & PL17 & No data & 35 & $\leq 65$ & PolyM $>$ alginate $>$ poly & $1-4$ & Exo-type & {$[56]$} \\
\hline
\end{tabular}

All of the activity was defined by measuring the increase in absorbance at $235 \mathrm{~nm}$

a The activity of A1-IV was calculated according to the method described by Fu et al. [66]

from Saccharophagus degradans co-displaying yeast has been reported to exhibit high sodium alginate-degrading activity, producing $1.98 \mathrm{~g} / \mathrm{l}$ of reducing sugars in $1 \mathrm{~h}$ [4]. However, its polysaccharide conversion rate was only $19.8 \%$, which was far lower than that of recombinant VxAly7D. When $0.27 \mu \mathrm{g}$ of the endo-type alginate lyase AlyPB1 and $4.5 \mu \mathrm{g}$ of AlyPB2 from Photobacterium sp. FC615 acted on alginate together, and the yield of monosaccharides was dramatically increased approximately sevenfold compared with that resulting from the action of AlyPB2 applied alone for $10 \mathrm{~min}$ [38]; however, it was still lower than that of recombinant VxAly7D at $37.6 \%$ at $1 \mathrm{~min}$. Therefore, whether recombinant VxAly7D is used alone or in combination with endo-type alginate lyases, it increases the monosaccharides yield and productivity.

In addition to enzyme activity, substrate specificity plays a key role in monosaccharide production by exo-type alginate lyases. Many exo-type alginate lyases present a significant substrate preference. For example, AlyGC from Glaciecola chathamensis $\mathrm{S} 18 \mathrm{~K} 6^{\mathrm{T}}$ [15], OalS6 from Shewanella sp. Kz7 [50], AlyA5 from Zobellia galactanivorans $\mathrm{Dsij}^{\mathrm{T}}$ [18], CaAly4 and CaAly5 from Cellulophaga algicola DSM 14237 [44], and OalC6 from Cellulophaga sp. SY116 prefer polyG blocks [30], while HdAlex from Haliotis discus hannai [34], OalC17 from Cellulophaga sp. SY116 [30] prefer polyM blocks. Although the combination of exo-type alginate lyases with different preferences could compensate for the disadvantage [30], multi-enzyme degradation is somewhat more complicated than single-enzyme degradation. Exotype alginate lyases with substrate preference are limited by the substrate blocks, which affects the industrial production of monosaccharide. As a bifunctional alginate lyase, recombinant VxAly7D exhibited similar activity towards polyM and polyG that was close to the activity towards sodium alginate, indicating that it could effectively degrade substrates of any block and drive the production process (Fig. 2g).

Mesophilic alginate lyases present optimal temperatures (usually $40-50{ }^{\circ} \mathrm{C}$ ) and are generally stable below $40{ }^{\circ} \mathrm{C}$ [51-54]. Compared with mesophilic homologs, alginate lyases, which exhibit higher activity and stability at low/moderate temperatures, provide economic benefits by reducing the energy cost of the production process [55]. These enzymes usually show high activity below $35^{\circ} \mathrm{C}$ and are stable below $30^{\circ} \mathrm{C}[27,56-58]$. The optimal temperature of recombinant VxAly7D was $30{ }^{\circ} \mathrm{C}$. Even at $0{ }^{\circ} \mathrm{C}$, recombinant VxAly7D exhibited $21 \%$ of its highest 
activity (Fig. 2d). Compared with exo-type alginate lyases from different PL families, recombinant VxAly7D still presented high activity $(415.8 \mathrm{U} / \mathrm{mg})$ in degrading substrates with different conformations to obtain monosaccharides at $20{ }^{\circ} \mathrm{C}$ (Table 3). Therefore, recombinant VxAly7D is more suitable for reaction conditions performed at room temperature without additional energy consumption.

According to the CAZy database, AlyA5 from Zobellia galactanivorans $\mathrm{Dsij}^{\mathrm{T}}$ is the only exo-type alginate lyase with available structural information and characterization results among PL7 family. The structural features leading to the exolytic action mode were predicted to be the three large additional loops $\left(\operatorname{Trp}^{197}-\mathrm{Asp}^{217}\right.$, $\mathrm{Ser}^{257}-\mathrm{Glu}^{284}$, and $\mathrm{Gly}^{304}$-Asp ${ }^{318}$ ) closed up one end of the catalytic groove $[18,43]$. In particular, $\operatorname{Trp}^{313}$ is located close to three conserved catalytic residues, forming a hydrophobic wall that obstructed the continuation of the catalytic groove [18]. The above three large additional loops of AlyA5 corresponded to VxAly7D as loop1, loop2, and loop3 (Fig. 6b). The results showed that loop1 and loop2 of VxAly7D were obviously shorter than those of AlyA5 (Fig. 6b). However, recombinant VxAly7D still exhibited exolytic activity (Fig. 4), indicating that loop3 might be the key structural feature leading to the exotype action mode. The results obtained for the loop3deletion mutant CL3 demonstrated that loop3 might not only affect the exo-type action mode of VxAly7D but, more importantly, might also affect its catalytic ability. Since the viscosity change associated with an endo-type action mode is more obvious than that for the exo-type action mode, the viscosity change cannot determine the action mode when both endo- and exo-type action modes occur [59]. Furthermore, the TLC analysis result of the time-course suggested that the W295A mutant, while retaining the exo-type action mode, also exhibited an endo-type action mode, resulting in the occurrence of oligosaccharides with other DPs during the degradation process (Fig. 7b-d). The change in the action mode of the W295A mutant indicated that the hydrophobic power generated by Trp was the main factor affecting the exotype action mode of PL7 alginate lyases.

\section{Conclusions}

In this study, we cloned and characterized an exo-type PL7 alginate lyase, VxAly7D, from the marine bacterium V. xiamenensis QY104. Recombinant VxAly7D is a bifunctional exo-type alginate lyase that exhibits high specific activity towards sodium alginate, polyG and polyM. For further industrial applications, recombinant VxAly7D exhibited high activity and stability at low/ moderate temperatures. Importantly, recombinant VxAly7D could quickly and highly efficiently convert sodium alginate to unsaturated monosaccharides. A total of $13 \mu \mathrm{g}$ recombinant VxAly7D could convert $3 \mathrm{mg}$ sodium alginate to unsaturated monosaccharides in $1 \mathrm{~min}$ with a yield of $37.6 \%$, and the yield reached $95 \%$ in $1 \mathrm{~h}$. Therefore, due to its high activity at low/moderate temperatures and broad substrate specificity, VxAly7D may become a potential tool enzyme for the production of unsaturated monosaccharides with low energy consumption, providing precursors for obtaining DEH. In addition, we demonstrated the mechanism of exolytic action mode of VxAly7D, promoting our understanding of the mechanism of alginate polysaccharide metabolism in marine ecosystems.

\section{Methods}

\section{Materials and strains}

Sodium alginate was obtained from the Bright Moon Seaweed Group (originating from brown algae, $600 \mathrm{cPs}$; Qingdao, China). High-viscosity sodium alginate was purchased from Sigma-Aldrich (originating from brown algae, 3330 cPs; St. Louis, MO, USA). PolyM and polyG (6-8 kDa) were purchased from Qingdao BZ Oligo Biotech Co., Ltd., Qingdao, China. The chemical reagents were all of analytical grade. Restriction enzymes and the pET-24a (+) vector plasmid were obtained from Takara Co., Ltd., Dalian, China. The high-fidelity DNA polymerase used for PCR was procured from Vazyme Biotech Co. Ltd., Nanjing, China. Primer synthesis and DNA sequencing were performed at the Beijing Genomics Institute (BGI).

Escherichia coli DH5 $\alpha$ was used for DNA cloning. E. coli BL21 (DE3) was used for recombinant protein expression. The marine bacterium V.xiamenensis QY104, isolated from seawater from Qingdao coast, was cultured at $25{ }^{\circ} \mathrm{C}$ in medium ( $\mathrm{pH} 7.0$ ) containing (w/v) $2.5 \% \mathrm{NaCl}$, $0.25 \%$ casamino acids, $0.1 \% \mathrm{KCl}, 0.5 \% \mathrm{MgSO}_{4} \cdot 7 \mathrm{H}_{2} \mathrm{O}$, $0.02 \% \mathrm{CaCl}_{2}, 0.15 \% \mathrm{NaH}_{2} \mathrm{PO}_{4}, 0.2 \% \mathrm{NaNO}_{3}, 0.002 \%$ $\mathrm{FeSO}_{4} \cdot 7 \mathrm{H}_{2} \mathrm{O}$ and $0.3 \%$ sodium alginate $(1.5 \%$ agar in solid medium). The bacterial genome was sequenced and assembled by Novogene (Beijing, China).

\section{Sequence analysis and homology modelling of VxAly7D}

The signal peptide was predicted using the SignalP 5.0 server (http://www.cbs.dtu.dk/services/SignalP/). The theoretical molecular weight $(\mathrm{Mw})$ and isoelectric point ( $\mathrm{pI}$ ) were calculated using the Compute $\mathrm{pI} /$ $\mathrm{Mw}$ tool (https://web.expasy.org/compute_pi/). The amino acid sequence alignment between VxAly7D and crystallized PL7 alginate lyases was obtained using ClustalW and further aligned with ESPript 3.0 (http:// espript.ibcp.fr/ESPript/cgi-bin/ESPript.cgi). The phylogenetic tree was constructed using MEGA 7.0 via the neighbour-joining method. The three-dimensional 
structure of VxAly7D was modelled with SWISSMODEL (https://swissmodel.expasy.org/) using AlyA5 (PDB ID: 4BE3) from Zobellia galactanivorans Dsij ${ }^{\mathrm{T}}$ as the template and was superimposed and described using PyMOL. The quality of the structure of VxAly7D was verified by Verify3D (https://servicesn.mbi.ucla. edu/Verify3d/). The sequence of VxAly7D was submitted to GenBank under Accession number MN704375.

\section{Cloning, overexpression and purification of recombinant VxAly7D and VxAly7D mutants}

The vxaly $7 D$ gene without the sequence encoding the signal peptide was amplified from $V$. xiamenensis QY104 genomic DNA by PCR. Using the restriction enzyme sites Nde I and Xho I, the PCR product was ligated into the expression vector pET-24a (+), obtaining a recombinant VxAly7D protein with a C-terminal (His) ${ }_{6}$-tag. The W295A and CL3 mutants were generated via overlap extension PCR with the pET-24a $(+)$ harbouring the VxAly7D sequence as the template. The primers used for these purposes are shown in Additional file 1: Table S2.

The verified recombinant plasmids were transformed into the E. coli BL21 (DE3) expression strain and cultured overnight at $37{ }^{\circ} \mathrm{C}$ on LB plates supplemented with $80 \mu \mathrm{g} / \mathrm{ml}$ kanamycin. Single colonies were inoculated into fresh kanamycin-containing LB medium and cultured for $16 \mathrm{~h}$ at $37^{\circ} \mathrm{C}$ at $160 \mathrm{rpm}$, and then transferred to $100 \mathrm{ml}$ kanamycin-containing LB medium and cultured at $160 \mathrm{rpm}$ at $37{ }^{\circ} \mathrm{C}$ until the $\mathrm{OD}_{600}$ reached 0.5 . Isopropyl- $\beta$-D-thiogalactopyranoside (IPTG) was added to a final concentration of $0.1 \mathrm{mM}$, followed by incubation for an additional $39 \mathrm{~h}$ at $18{ }^{\circ} \mathrm{C}$.

Cell pellets were harvested at $12,000 \mathrm{rpm}$ at $4{ }^{\circ} \mathrm{C}$ for $15 \mathrm{~min}$, then resuspended in binding buffer $[20 \mathrm{mM}$ $\mathrm{Na}_{2} \mathrm{HPO}_{4}-\mathrm{NaH}_{2} \mathrm{PO}_{4}$ buffer (PB), $500 \mathrm{mM} \mathrm{NaCl}, \mathrm{pH}$ 7.3] and crushed with a high-pressure crusher (JNBIO, Guangzhou China). Cell debris was removed by centrifugation at $12,000 \mathrm{rpm}$ for $20 \mathrm{~min}$, and the supernatant was collected as the crude enzyme solution. The crude enzyme solution was purified by ÄKTA Fast Protein Liquid Chromatography (FPLC) with a 5-ml Ni-NTA Sepharose column (GE Healthcare, Stamford, USA) at a flow rate of $2 \mathrm{ml} / \mathrm{min}$. Binding buffer was used to remove unbound protein. The proteins were eluted in fractions containing 25, 100, 250 and $500 \mathrm{mM}$ imidazole in washing buffer, and the target protein was successfully recovered at the imidazole concentration of $250 \mathrm{mM}$. The purity and molecular mass of the protein were analysed by $12.5 \%(\mathrm{w} / \mathrm{v})$ sodium dodecyl sulfate-polyacrylamide gel electrophoresis (SDS-PAGE).

\section{Enzymatic activity assay}

The reaction mixture included $0.1 \mathrm{ml}$ of purified enzyme solution and $0.9 \mathrm{ml}$ of $0.3 \%$ sodium alginate $(\mathrm{w} / \mathrm{v})$ in $\mathrm{PB}$ containing $100 \mathrm{mM} \mathrm{NaCl}(\mathrm{pH} 7.3)$ and was incubated for $10 \mathrm{~min}$ at $30{ }^{\circ} \mathrm{C}$. The alginate lyase activities of recombinant VxAly7D and the mutants were assayed by measuring the increase in the absorbance at $235 \mathrm{~nm}\left(\mathrm{~A}_{235}\right)$ for the unsaturated product. One unit $(\mathrm{U})$ of activity was defined as an increase in the $A_{235}$ value of 0.1 per min. The protein concentration was measured with BCA Protein Quantification Kits (Vazyme Biotech Co. Ltd., Nanjing, China).

\section{Biochemical characterization of recombinant VxAly7D and the W295A mutant}

Buffers with different $\mathrm{pH}$ values were used to measure the optimal $\mathrm{pH}$ and $\mathrm{pH}$ stability, including $50 \mathrm{mM}$ $\mathrm{Na}_{2} \mathrm{HPO}_{4}$-citric acid buffer ( $\mathrm{pH}$ 3.0-8.0), $50 \mathrm{mM}$ $\mathrm{Na}_{2} \mathrm{HPO}_{4}-\mathrm{NaH}_{2} \mathrm{PO}_{4}$ buffer (pH 6.0-7.6), $50 \mathrm{mM}$ Tris$\mathrm{HCl}$ buffer (pH 7.05-8.95) and $50 \mathrm{mM} \mathrm{Gly-NaOH}$ buffer (pH 8.6-10.6). The optimal pH of recombinant VxAly7D and the W295A mutant was determined in each buffer at $30{ }^{\circ} \mathrm{C}$ and assayed as described above. For the determination of $\mathrm{pH}$ stability, residual activity was detected after the incubation of recombinant VxAly7D and the W295A mutant in different buffers for $12 \mathrm{~h}$ at $4{ }^{\circ} \mathrm{C}$. The optimal temperature was measured by incubation for $10 \mathrm{~min}$ at the optimal $\mathrm{pH}$ at various temperatures $(0,10,20,30$, 40,50 and $60^{\circ} \mathrm{C}$ ). Temperature stability was determined by measuring residual activity after incubation for $1 \mathrm{~h}$ at different temperatures. In addition, the temperature stability was also investigated by measuring the residual activity after incubating the recombinant VxAly7D at $20{ }^{\circ} \mathrm{C}$ and $30^{\circ} \mathrm{C}$ for $0-24 \mathrm{~h}$. Enzyme activity was measured at the optimal $\mathrm{pH}$ in $0.3 \%(\mathrm{w} / \mathrm{v})$ sodium alginate containing $0,0.1,0.25,0.5,0.75$ or $1.0 \mathrm{mM} \mathrm{NaCl}$ to determine $\mathrm{NaCl}$ dependence. For the investigation of substrate specificity, $0.3 \%(\mathrm{w} / \mathrm{v})$ sodium alginate, polyM and polyG were used as substrates.

\section{Action mode and end products of recombinant VxAly7D and the W295A mutant}

To determine the action mode of recombinant VxAly7D and the W295A mutant, $1 \mathrm{ml}$ enzyme (10 U) was added to $9 \mathrm{ml}$ substrate solution [0.3\% (w/v) high-viscosity sodium alginate, $100 \mathrm{mM} \mathrm{NaCl}, 20 \mathrm{mM} \mathrm{PB}$, optimal $\mathrm{pH}$ ], followed by incubation at $30^{\circ} \mathrm{C}$ for $0,1,5,10,30$ and 60 min. The changes in viscosity and $\mathrm{A}_{235}$ were measured with a viscometer and UV detector. In addition, to detect the absorption change of the products of recombinant VxAly7D at $235 \mathrm{~nm}, 12 \mathrm{U}$ recombinant VxAly7D was added to $1 \mathrm{ml}$ substrate solution $[0.3 \%(\mathrm{w} / \mathrm{v})$ sodium 
alginate, $100 \mathrm{mM} \mathrm{NaCl}, 20 \mathrm{mM} \mathrm{PB}$, optimal pH], followed by incubation at $30^{\circ} \mathrm{C}$ for $0,5,15,20,30,40,55,80$ and $90 \mathrm{~min}$. The changes in A235 were measured with a UV detector.

Then, the degradation products obtained from the time-course analysis of recombinant VxAly7D and the W295A mutant were further characterized using thinlayer chromatography (TLC) as previously reported [60]. A total of $5 \mathrm{U}$ enzyme was added to $1 \mathrm{ml}$ substrate solution $[0.3 \%(\mathrm{w} / \mathrm{v})$ substrate in $20 \mathrm{mM}$ PB supplemented with $100 \mathrm{mM} \mathrm{NaCl}$, optimal $\mathrm{pH}$ ], followed by incubation at $30{ }^{\circ} \mathrm{C}$ for $0 \mathrm{~s}, 10 \mathrm{~s}, 30 \mathrm{~s}, 1 \mathrm{~min}, 3 \mathrm{~min}, 5 \mathrm{~min}, 10 \mathrm{~min}$, $20 \mathrm{~min}, 30 \mathrm{~min}, 40 \mathrm{~min}$, and $60 \mathrm{~min}$. In brief, the reaction was stopped by boiling for $5 \mathrm{~min}$, and the degradation products were separated in TLC aluminium silica gel plates (Merck, Germany) developed with $n$-butanol/ formic acid/water (4:6:1, v:v:v). They were visualized via the 1,3-naphthalenediol staining method as previously reported [60, 61].

To obtain the end products, each enzyme was added to $1 \mathrm{ml}$ of substrate solution $[0.3 \%(\mathrm{w} / \mathrm{v})$ sodium alginate in $20 \mathrm{mM}$ PB supplemented with $100 \mathrm{mM} \mathrm{NaCl}$, opti$\mathrm{mal} \mathrm{pH}$ ] to a final concentration of $20 \mathrm{U} / \mathrm{ml}$ or $100 \mathrm{U} / \mathrm{ml}$, followed by culture at $30{ }^{\circ} \mathrm{C}$ for $16 \mathrm{~h}$. To determine the components of the end products, TLC analysis of the end products was carried out according to the above method. Then, FPLC with a Superdex peptide 10/300 gel filtration column (GE Health, USA) was applied. The flow rate of the mobile phase $\left(0.2 \mathrm{M} \mathrm{NH}_{4} \mathrm{HCO}_{3}\right)$ was $0.2 \mathrm{ml} / \mathrm{min}$, and the absorbance was monitored at $235 \mathrm{~nm}$. Additionally, the end products mixed with acetonitrile $1: 1(\mathrm{v} / \mathrm{v})$ were detected from 150 to $2000 \mathrm{~m} / \mathrm{z}$ by negative ion electrospray ionization mass spectrometry (ESI-MS) to determine their molecular weight.

\section{Supplementary information}

Supplementary information accompanies this paper at https://doi. org/10.1186/s13068-020-01738-4.

Additional file 1: Table S1. Effect of metal ions, chelators, and detergents on the W295A mutant activity. Table S2. PCR primers for the recombinant VxAly7D and the W295A and CL3 mutants. Fig. S1. Negative ion ESI-MS analysis of the end products of recombinant VxAly7D. Fig. S2. Purity analysis and biochemical characterization of the W295A mutant. Fig. S3.

TLC analysis of the end products of the W295A mutant towards polyM and polyG. Fig. S4. Negative ion ESI-MS analysis of the end products of the W295A mutant.

\section{Abbreviations}

$\triangle:$ 4-Deoxy-L-erythro-5-hexoseulose uronic acid; DP: Degree of polymerization; G: Guluronate; M: Mannuronate; PolyG: Polyguluronate; PolyM: Polymannuronate; SDS-PAGE: Sodium dodecyl sulfate-polyacrylamide gel electrophoresis; PL family: Polysaccharide lyase family; $\mathrm{PB}: \mathrm{Na}_{2} \mathrm{HPO}_{4}-\mathrm{NaH}_{2} \mathrm{PO}_{4}$ buffer; $\triangle \mathrm{DP} 1$ : Unsaturated monosaccharides; $\triangle \mathrm{DP} 2$ : Unsaturated disaccharides; $\triangle \mathrm{DP} 3$ : Unsaturated trisaccharides; DP1: Saturated monosaccharides; CAZy database: Carbohydrate-Active enZYmes database; DEH: 4-Deoxy-L-erythro-5-hexoseulose uronate; KDG: 2-Keto-3-deoxygluconate; ED pathway: Entner-Doudoroff pathway; EDTA: Ethylenediaminetetraacetic acid; DTT: Dithiothreitol; EGTA : Ethylenebis (oxyethylenenitrilo) tetraacetic acid; FPLC: Fast protein liquid chromatography; IPTG: Isopropyl- $\beta$-D-thiogalactopyranoside.

\section{Authors' contributions}

LYT and YW designed the study under the guidance of FH and WGY. Funding was secured by FH and WGY. LYT, YW and FH drafted and corrected the manuscript. LYT, YW, SG, HW and DNW carried out the experiments, collected and analysed data. All authors read and approved the final manuscript.

\section{Author agreements \\ All authors agree to publish this article.}

\section{Funding and acknowledgements}

This work was supported by National Science and Technology Major Project for Significant New Drugs Development (2018ZX09735004), Marine S\&T

Fund of Shandong Province for Pilot National Laboratory for Marine Science and Technology (Qingdao) (2018SDKJ0401-2), National Key R\&D Program of China (2018YFC0311105), Natural Science Foundation of Shandong Province (ZR2018MD021), and National Science Foundation of China (31000361).

\section{Availability of data and materials \\ Not applicable.}

\section{Ethics approval and consent to participate}

Not applicable.

\section{Consent for publication}

Not applicable.

\section{Competing interests}

The authors declare that they have no competing interests.

\section{Author details}

${ }^{1}$ Key Laboratory of Marine Drugs, Ministry of Education; Shandong Provincial Key Laboratory of Glycoscience and Glycoengineering, School of Medicine and Pharmacy, Ocean University of China, 5 Yushan Road, Qingdao 266003, China. ${ }^{2}$ Laboratory for Marine Drugs and Bioproducts of Qingdao National Laboratory for Marine Science and Technology, Qingdao 266237, China. ${ }^{3}$ Biology Institute, Qilu University of Technology (Shandong Academy of Sciences), Jinan 250103, Shandong, China.

Received: 13 February 2020 Accepted: 22 May 2020

Published online: 01 June 2020

\section{References}

1. Carvalho AKF, Rivaldi JD, Barbosa JC, de Castro HF. Biosynthesis, characterization and enzymatic transesterification of single cell oil of Mucor circinelloides - a sustainable pathway for biofuel production. Bioresour Technol. 2015;181:47-53.

2. John RP, Anisha GS, Nampoothiri KM, Pandey A. Micro and macroalgal biomass: a renewable source for bioethanol. Bioresour Technol. 2011;102(1):186-93.

3. Ge L, Wang P, Mou H. Study on saccharification techniques of seaweed wastes for the transformation of ethanol. Renew Energy. 2011;36(1):84-9.

4. Takagi T, Yokoi T, Shibata T, Morisaka H, Kuroda K, Ueda M. Engineered yeast whole-cell biocatalyst for direct degradation of alginate from macroalgae and production of non-commercialized useful monosaccharide from alginate. Appl Microbiol Biotechnol. 2016;100(4):1723-32.

5. Ji SQ, Wang B, Lu M, Li FL. Direct bioconversion of brown algae into ethanol by thermophilic bacterium Defluviitalea phaphyphila. Biotechnol Biofuels. 2016:9:81.

6. Wargacki AJ, Leonard E, Win MN, Regitsky DD, Santos CNS, Kim PB, Cooper SR, Raisner RM, Herman A, Sivitz AB, Lakshmanaswamy A, Kashiyama Y, Baker D, Yoshikuni Y. An engineered microbial platform for direct biofuel production from brown macroalgae. Science. 2012;335(6066):308-13. 
7. Popper ZA, Michel G, Herve C, Domozych DS, Willats WG, Tuohy MG, Kloareg B, Stengel DB. Evolution and diversity of plant cell walls: from algae to flowering plants. Annu Rev Plant Biol. 2011;62:567-90.

8. Kloareg B, Demarty M, Mabeau S. Ion-exchange properties of isolated cell walls of brown algae: the interstitial solution. J Exp Bot. 1987;38(10):1652-62.

9. Gacesa P. Alginates. Carbohydr Polym. 1988;8(3):161-82.

10. Sellimi S, Younes I, Ayed H, Maalej H, Montero V, Rinaudo M, Dahia M, Mechichi T, Hajji M, Nasri M. Structural, physicochemical and antioxidant properties of sodium alginate isolated from a Tunisian brown seaweed. Int J Biol Macromol. 2014;72:1358-67.

11. Tang JC, Taniguchi H, Chu H, Zhou Q, Nagata S. Isolation and characterization of alginate degrading bacteria for disposal of seaweed wastes. Lett Appl Microbiol. 2008;48(1):38-43.

12. Liu J, Yang S, Li X, Yan Q, Reaney MJT, Jiang Z. Alginate oligosaccharides: production, biological activities, and potential applications. Compr Rev Food Sci Food Saf. 2019;18(6):1859-81.

13. Wong TY, Preston LA, Schiller NL. Alginate lyase: review of major sources and enzyme characteristics, structure-function analysis, biological roles, and applications. Annu Rev Microbiol. 2000;54(1):289-340.

14. Gao S, Zhang Z, Li S, Su H, Tang L, Tan Y, Yu W, Han F. Characterization of a new endo-type polysaccharide lyase (PL) family 6 alginate lyase with cold-adapted and metal ions-resisted property. Int J Biol Macromol. 2018;120:729-35.

15. Xu F, Dong F, Wang P, Cao HY, Li CY, Li PY, Pang XH, Zhang YZ, Chen XL. Novel molecular insights into the catalytic mechanism of marine bacterial alginate lyase AlyGC from polysaccharide lyase family 6. J Biol Chem. 2017;292(11):4457-68.

16. Chen XL, Dong S, Xu F, Dong F, Li PY, Zhang XY, Zhou BC, Zhang YZ, Xie BB. Characterization of a new cold-adapted and salt-activated polysaccharide lyase family 7 alginate lyase from Pseudoalteromonas sp. SM0524. Front Microbiol. 2016;7:1120.

17. Rauch ME, Graef HW, Rozenzhak SM, Jones SE, Bleckmann CA, Kruger RL, Naik RR, Stone MO. Characterization of microbial contamination in United States Air Force aviation fuel tanks. J Ind Microbiol Biotechnol. 2006;33(1):29-36.

18. Thomas F, Lundqvist LC, Jam M, Jeudy A, Barbeyron T, Sandstrom C, Michel G, Czjzek M. Comparative characterization of two marine alginate lyases from Zobellia galactanivorans reveals distinct modes of action and exquisite adaptation to their natural substrate. J Biol Chem. 2013;288(32):23021-37.

19. Li S, Yang X, Zhang L, Yu W, Han F. Cloning, expression, and characterization of a cold-adapted and surfactant-stable alginate lyase from marine bacterium Agarivorans sp. L11. J Microbiol Biotechnol. 2015;25(5):681-6.

20. Dong S, Yang J, Zhang X-Y, Shi M, Song X-Y, Chen X-L, Zhang Y-Z. Cultivable alginate lyase-excreting bacteria associated with the Arctic brown alga Laminaria. Mar Drugs. 2012;10(11):2481-91.

21. Vester J, Glaring M, Stougaard P. Discovery of novel enzymes with industrial potential from a cold and alkaline environment by a combination of functional metagenomics and culturing. Microb Cell Fact. 2014;13(1):72.

22. De Santi C, Tedesco P, Ambrosino L, Altermark B, Willassen NP, de Pascale D. A new alkaliphilic cold-active esterase from the psychrophilic marine bacterium Rhodococcus sp.: functional and structural studies and biotechnological potential. Appl Biochem Biotechnol. 2014;172(6):3054-68.

23. Hu X, Jiang $X$, Hwang HM. Purification and characterization of an alginate lyase from marine Bacterium Vibrio sp. mutant strain 510-64. Curr Microbiol. 2006:53(2):135-40.

24. Wang B, Ji S-Q, Lu M, Li F-L. Biochemical and structural characterization of alginate lyases: an update. Curr Biotechnol. 2015;4(3):223-39.

25. Kim HS, Lee C-G, Lee EY. Alginate lyase: structure, property, and application. Biotechnol Bioprocess Eng. 2011;16(5):843-51.

26. Inoue A, Anraku M, Nakagawa S, Ojima T. Discovery of a novel alginate lyase from Nitratiruptor sp. SB155-2 thriving at deep-sea hydrothermal vents and identification of the residues responsible for its heat stability. J Biol Chem. 2016;291(30):15551-63.

27. Huang G, Wang Q, Lu M, Xu C, Li F, Zhang R, Liao W, Huang S. AlgM4: a new salt-activated alginate lyase of the PL7 family with endolytic activity. Mar Drugs. 2018;16(4):120.

28. Nakata S, Murata K, Hashimoto W, Kawai S. Uncovering the reactive nature of 4-deoxy-L-erythro-5-hexoseulose uronate for the utilization of alginate, a promising marine biopolymer. Sci Rep. 2019;9(1):1-11.
29. Yu Z, Zhu B, Wang W, Tan H, Yin H. Characterization of a new oligoalginate lyase from marine bacterium Vibrio sp. Int J Biol Macromol. 2018:112:937-42.

30. Li S, Wang L, Chen X, Zhao W, Sun M, Han Y. Cloning, expression, and biochemical characterization of two new oligoalginate lyases with synergistic degradation capability. Mar Biotechnol. 2018;20(1):75-86.

31. Park HH, Kam N, Lee EY, Kim HS. Cloning and characterization of a novel oligoalginate lyase from a newly isolated bacterium Sphingomonas sp. MJ-3. Mar Biotechnol. 2012;14(2):189-202.

32. Park D, Jagtap S, Nair SK. Structure of a PL17 family alginate lyase demonstrates functional similarities among exotype depolymerases. J Biol Chem. 2014:289(12):8645-55.

33. Ochiai A, Hashimoto W, Murata K. A biosystem for alginate metabolism in Agrobacterium tumefaciens strain C58: molecular identification of Atu3025 as an exotype family PL-15 alginate lyase. Res Microbiol. 2006;157(7):642-9.

34. Suzuki H, Suzuki K, Inoue A, Ojima T. A novel oligoalginate lyase from abalone, Haliotis discus hannai, that releases disaccharide from alginate polymer in an exolytic manner. Carbohydr Res. 2006;341 (11):1809-19.

35. Ochiai A, Yamasaki M, Mikami B, Hashimoto W, Murata K. Crystal structure of exotype alginate lyase Atu3025 from Agrobacterium tumefaciens. J Biol Chem. 2010;285(32):24519-28.

36. Hashimoto W, Miyake O, Momma K, Kawai S, Murata K. Molecular identification of oligoalginate lyase of Sphingomonas sp. strain A1 as one of the enzymes required for complete depolymerization of alginate. J Bacteriol. 2000;182(16):4572-7.

37. MacDonald LC, Weiler EB, Berger BW. Engineering broad-spectrum digestion of polyuronides from an exolytic polysaccharide lyase. Biotechnol Biofuels. 2016:9:43.

38. Lu D, Zhang Q, Wang S, Guan J, Jiao R, Han N, Han W, Li F. Biochemical characteristics and synergistic effect of two novel alginate lyases from Photobacterium sp. FC615. Biotechnol Biofuels. 2019;12:260.

39. Gimpel JA, Ravanal MC, Salazar O, Lienqueo ME. Saccharification of brown macroalgae using an arsenal of recombinant alginate lyases: potential application in the biorefinery process. J Microbiol Biotechnol. 2018;28(10):1671-82.

40. Zhu B, Ni F, Sun Y, Ning L, Yao Z. Elucidation of degrading pattern and substrate recognition of a novel bifunctional alginate lyase from Flammeovirga sp. NJ-04 and its use for preparation alginate oligosaccharides. Biotechnol Biofuels. 2019;12:13.

41. Zhu B, Yin H. Alginate lyase: review of major sources and classification, properties, structure-function analysis and applications. Bioengineered. 2015;6(3):125-31.

42. Eisenberg D, Lüthy R, Bowie JU. VERIFY3D: assessment of protein models with three-dimensional profiles. Nature. 1992;356(6364):83-5.

43. Xu F, Wang P, Zhang YZ, Chen XL. Diversity of three-dimensional structures and catalytic mechanisms of alginate lyases. Appl Environ Microbiol. 2018;84(3):e02040-17.

44. Fischer A, Wefers D. Chromatographic analysis of alginate degradation by five recombinant alginate lyases from Cellulophaga algicola DSM 14237. Food Chem. 2019;299:125142.

45. Hirayama M, Hashimoto W, Murata K, Kawai S. Comparative characterization of three bacterial exo-type alginate lyases. Int J Biol Macromol. 2016;86:519-24.

46. Badur AH, Jagtap SS, Yalamanchili G, Lee JK, Zhao H, Rao CV. Alginate lyases from alginate-degrading Vibrio splendidus 12B01 are endolytic. Appl Environ Microbiol. 2015;81(5):1865-73.

47. Yang $X, L i S$, W Y Y, Yu W, Han F. Cloning and characterization of two thermo- and salt-tolerant oligoalginate lyases from marine bacterium Halomonas sp. FEMS Microbiol Lett. 2016;363:fnw079.

48. Mori T, Takahashi M, Tanaka R, Miyake H, Shibata T, Chow S, Kuroda K, Ueda M, Takeyama H. Falsirhodobacter sp. alg1 harbors single homologs of endo and exo-Type alginate lyases efficient for alginate depolymerization. PLOS ONE. 2016;11(5):e0155537.

49. He M, Guo M, Zhang X, Chen K, Yan J, Irbis C. Purification and characterization of alginate lyase from Sphingomonas sp. ZHO. J Biosci Bioeng. 2018;126(3):310-6.

50. Li S, Wang L, Han F, Gong Q, Yu W. Cloning and characterization of the first polysaccharide lyase family 6 oligoalginate lyase from marine Shewanella sp. Kz7. J Biochem. 2015;159(1):77-86. 
51. Pei X, Chang Y, Shen J. Cloning, expression and characterization of an endo-acting bifunctional alginate lyase of marine bacterium Wenyingzhuangia fucanilytica. Protein Expr Purif. 2019;154:44-51.

52. Yagi H, Fujise A, Itabashi N, Ohshiro T. Characterization of a novel endo-type alginate lyase derived from Shewanella sp YH1. J Biochem. 2018;163(4):341-50.

53. Yagi H, Isobe N, Itabashi N, Fujise A, Ohshiro T. Characterization of a longlived alginate lyase derived from Shewanella species YH1. Mar Drugs. 2017;16(1):4.

54. Han F, Gong QH, Song K, Li JB, Yu WG. Cloning, sequence analysis and expression of gene alyVI encoding alginate lyase from marine bacterium Vibrio sp. QY101. DNA Seq. 2004;15(5-6):344-50.

55. Duarte AWF, Dos Santos JA, Vianna MV, Vieira JMF, Mallagutti VH, Inforsato FJ, Wentzel LCP, Lario LD, Rodrigues A, Pagnocca FC, Pessoa Junior A, Duraes Sette L. Cold-adapted enzymes produced by fungi from terrestrial and marine Antarctic environments. Crit Rev Biotechnol. 2018;38(4):600-19.

56. Jiang Z, Guo Y, Wang X, Li H, Ni H, Li L, Xiao A, Zhu Y. Molecular cloning and characterization of AlgL17, a new exo-oligoalginate lyase from Microbulbifer sp. ALW1. Protein Expr Purif. 2019:161:17-27.

57. Hu F, Li Q, Zhu B, Ni F, Sun Y, Yao Z. Effects of module truncation on biochemical characteristics and products distribution of a new alginate lyase with two catalytic modules. Glycobiology. 2019;29(12):876-84.

58. Daboor SM, Raudonis R, Cohen A, Rohde JR, Cheng Z. Marine bacteria, a source for alginolytic enzyme to disrupt Pseudomonas aeruginosa biofilms. Mar Drugs. 2019; 17(5).

59. Temuujin U, Chi WJ, Chang YK, Hong SK. Identification and biochemical characterization of Sc03487 from Streptomyces coelicolor A3(2), an exo- and endo-type $\beta$-agarase-producing neoagarobiose. J Bacteriol. 2011;194(1):142-9.
60. Inoue A. Characterization of PL-7 family alginate lyases from marine organisms and their applications. Method Enzymol. 2018;605:499-524.

61. Bonn G, Grünwald M, Scherz H, Bobleter O. Thin-layer electrophoretic behaviour of oligo- and monosaccharides, uronic acids and polyhydroxy compounds obtained as biomass degradation products. J Chromatogr A. 1986;370(3):485-93.

62. Zhu B, Tan H, Qin Y, Xu Q, Du Y, Yin H. Characterization of a new endo-type alginate lyase from Vibrio sp. W13. Int J Biol Macromol. 2015;75:330-7.

63. Rahman MM, Inoue A, Tanaka H, Ojima T. cDNA cloning of an alginate lyase from a marine gastropod Aplysia kurodai and assessment of catalytically important residues of this enzyme. Biochimie. 2011;93(10):1720-30.

64. Qin HM, Miyakawa T, Inoue A, Nishiyama R, Nakamura A, Asano A Sawano Y, Ojima T, Tanokura M. Structure and polymannuronate specificity of a eukaryotic member of polysaccharide lyase family 14. J Biol Chem. 2017;292:2182-90.

65. Miyake O, Hashimoto W, Murata K. An exotype alginate lyase in Sphingomonas sp. A1: overexpression in Escherichia coli, purification, and characterization of alginate lyase IV (A1-IV). Protein Expres Purif. 2003;29(1):33-41.

66. Fu XT, Lin H, Kim SM. Purification and characterization of a $\mathrm{Na}^{+} / \mathrm{K}^{+}$ dependent alginate lyase from turban shell gut Vibrio sp. YKW-34. Enzyme Microb Technol. 2007;41(6-7):828-34.

\section{Publisher's Note}

Springer Nature remains neutral with regard to jurisdictional claims in published maps and institutional affiliations.
Ready to submit your research? Choose BMC and benefit from:

- fast, convenient online submission

- thorough peer review by experienced researchers in your field

- rapid publication on acceptance

- support for research data, including large and complex data types

- gold Open Access which fosters wider collaboration and increased citations

- maximum visibility for your research: over 100M website views per year

At BMC, research is always in progress.

Learn more biomedcentral.com/submissions 